\title{
Article \\ Flexural Strength Evaluation of Multi-Cell Composite L-Shaped Concrete-Filled Steel Tubular Beams
}

\author{
Yanfei Shen ${ }^{1,2} \mathbb{D}$, Yongqing Tu ${ }^{1, *}$ and Wei Huang ${ }^{1}$ \\ 1 Department of Civil Engineering, Beihang University, Beijing 100191, China; shenyanfei@wyu.edu.cn (Y.S.); \\ juzinanhai@sina.cn (W.H.) \\ 2 School of Civil and Architectural Engineering, Wuyi University, Jiangmen 529020, China \\ * Correspondence: tuyongqing@buaa.edu.cn
}

Citation: Shen, Y.; Tu, Y.; Huang, W. Flexural Strength Evaluation of Multi-Cell Composite L-Shaped Concrete-Filled Steel Tubular Beams. Buildings 2022, 12, 39. https:// doi.org/10.3390/buildings12010039

Academic Editor: Nerio Tullini

Received: 30 November 2021

Accepted: 30 December 2021

Published: 3 January 2022

Publisher's Note: MDPI stays neutral with regard to jurisdictional claims in published maps and institutional affiliations.

Copyright: (C) 2022 by the authors. Licensee MDPI, Basel, Switzerland. This article is an open access article distributed under the terms and conditions of the Creative Commons Attribution (CC BY) license (https:// creativecommons.org/licenses/by/ $4.0 /)$.

\begin{abstract}
Concrete-filled steel tubular (CFST) members have been widely used in industrial structures and high-rise residential buildings. The multi-cell composite L-shaped concrete-filled steel tubular (ML-CFST) cross-section, as an innovative, special-shaped structural arrangement, may solve the issue of normal CFST members protruding from walls and result in more usable interior space. Currently, no design rules are available for the application of ML-CFST members. One of the primary objectives of the present study is to develop recommendations in line with the unified theory to evaluate the bending moment resistance of ML-CFST beams. According to the unified theory, the bending moment resistance of an ML-CFST beam is related to the compressive strength $\left(\mathrm{f}_{\mathrm{SC}}\right)$ and the flexural strength index $\left(\gamma_{\mathrm{m}}\right)$ of a composite section, in which the accuracy of $\gamma_{\mathrm{m}}$ and $\mathrm{f}_{\mathrm{sc}}$ are affected by a confinement effect factor $(\xi)$. Nevertheless, the original expression of $\xi$ is not suitable for ML-CFST sections, since the appreciable effect of the irregular shape on confinement is neglected. Considering the cross-sectional geometry and boundary conditions of the cells, an equivalent shape factor to modify the confinement effect was proposed in this study through dividing the infill concrete into highly confined areas and less confined areas. An adequate formula to calculate the $\mathrm{f}_{\mathrm{sc}}$ and an approximate expression of $\gamma_{\mathrm{m}}$ for the ML-CFST sections was then developed. Furthermore, fourpoint bending tests on eight specimens were carried out to investigate the flexural performance of the ML-CFST beams. Lastly, the proposed formulas were assessed against experimental and numerical results. The comparisons show that the proposed unified theory-based approach produced accurate and generally conservative results for the ML-CFST beams studied.
\end{abstract}

Keywords: L-shaped; CFST; flexural strength; beam; unified theory; equivalent shape factor; confinement effect

\section{Introduction}

Concreted-filled steel tubular (CFST) members with favorable structural performances, low material consumptions, light structural self-weight, and low constructional expenses have been widely used in industrial structures and high-rise residential buildings [1-9]. In comparison to their reinforced concrete or steel counterparts, CFST members exhibit an improved structural strength, stiffness, and ductility [1,5]. The application of CFST members promotes the use of pre-fabricated and assembled structures and reduces construction time. To solve the problem of normal CFST members protruding from walls, a multi-cell composite L-shaped concrete-filled steel tubular (ML-CFST) cross-section, as shown in Figure 1, was proposed by $\mathrm{Li}$ and $\mathrm{Tu}$ [10]. This structural arrangement results in more usable interior space. For the fabrication of an ML-CFST member, two identical rectangular (or square) steel tubes are first welded to a single square steel tube, and concrete is then poured into the steel tubes. 


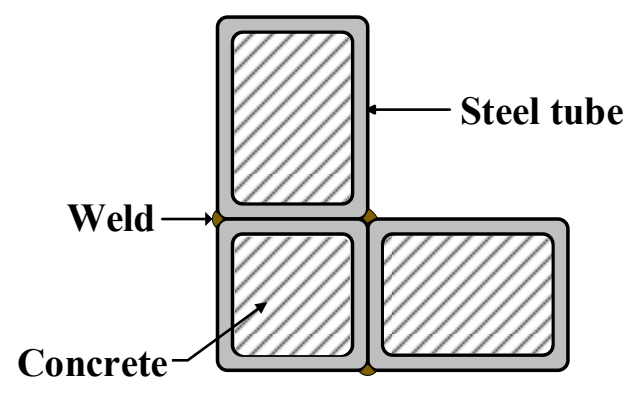

Figure 1. A typical ML-CFST cross-section.

Presently, there are no specific design provisions for implementing ML-CFST members in practice. Eurocode 4 [11] and AISC 360-16 [12] cover circular, square, and rectangular CFST members, while GB 50936-2014 [13] also targets octagonal and hexadecagonal CFST cross-sections. The plastic stress distribution method, which assumes that the steel achieves yield strength and that the concrete in the compression zone achieves a stress level equal to the concrete compressive strength $\left(f_{c}^{\prime}\right)$ multiplied by a shape factor, is adopted in both Eurocode 4 [11] and AISC 360-16 [12] to determine the bending moment resistance of CFST beams with compact sections. However, the large amount of calculation work needede.g., determining the location of the plastic neutral axis through the force equilibrium of the composite section, calculating the centroid of the tensile concrete, and calculating the respective centroids of the steel in compression and tension-makes the plastic stress distribution method impracticable to ML-CFST sections.

Different from Eurocode 4 [11] and AISC 360-16 [12], GB 50936-2014 [13] adopts the unified theory to determine the bending moment resistance of CFST beams. The unified theory considers steel tubes integrated with infill concrete as a new composite material, and a CFST member is taken as a single entity in the determination of its ultimate capacity under various loading conditions [14,15]. According to GB 50936-2014 [13], the unified theory-based formula used to evaluate the bending moment resistance of CFST beams with regular cross-sections is given by

$$
\mathrm{M}_{\mathrm{u}}=\gamma_{\mathrm{m}} \mathrm{W}_{\mathrm{sc}} \mathrm{f}_{\mathrm{sc}}
$$

where $\gamma_{\mathrm{m}}$ is the flexural strength index, $\mathrm{W}_{\mathrm{sc}}$ is the section modulus (corresponding to the extreme compression fiber), and $\mathrm{f}_{\mathrm{sc}}$ is the compressive strength of a CFST section. The development of formulas for calculating $\gamma_{\mathrm{m}}$ and $\mathrm{f}_{\mathrm{sc}}$ is based on regression analysis and calibration against test results. However, the $\gamma_{\mathrm{m}}$ and $\mathrm{f}_{\mathrm{sc}}$ provided in [13] are only applicable to CFST beams with regular cross-sections, such as quadrilateral, hexagonal, and octagonal cross-sections. Therefore, adequate expressions of $\gamma_{\mathrm{m}}$ and $\mathrm{f}_{\mathrm{sc}}$ in line with the unified theory for ML-CFST beams should be developed.

A number of studies have been carried out to assess the flexural strength (bending moment resistance) of CFST beams with conventional cross-sections [16-21]. Li et al. [18] performed four-point bending tests on square CFST beams with different steel-to-concrete ratios (steel area divided by concrete area), in which the accuracy of the unified theorybased formula specified in GB 50936-2014 [13] was assessed. It was found that the bending moment resistance determined in accordance with GB 50936-2014 [13] was generally consistent with the experimental and numerical results. For convenience of practical design, Han $[19,20]$ simplified the calculation of $\mathrm{f}_{\mathrm{sc}}$ included in the unified theory-based formula specified in [13]. The accuracy of Han's simplified formula [19,20] was verified against the test results of 51 normal CFST beams (circular, square, and rectangular cross-sections) collected in [19], 18 circular and 18 square CFST beams reported in [20], and 12 circular and 8 rectangular CFST beams reported in [21]. The comparisons showed that the simplified formula gave accurate and conservative predictions for the majority of the CFST beams, while it produced acceptable unconservative errors for a small number of square and rectangular CFST beams. Only a limited number of studies on special-shaped CFST beams 
have been reported so far. Shen and Tu [22] investigated the bending moment resistance of multi-cell T-shaped CFST members and assessed the accuracy of both a proposed unified theory-based approach and the plastic stress distribution method. It was found that the proposed unified theory-based approach gave improved predictions with reasonable conservative errors.

The following sections of the present paper mainly focus on four aspects: (1) developing an adequate formula to determine the compressive strength of the ML-CFST sections, followed by verification against numerical results; (2) proposing an approximate expression of $\gamma_{m}$ for ML-CFST beams based on numerical data; (3) conducting an experimental study of eight ML-CFST beams; and (4) evaluating the accuracy of the proposed formulas through comparing the predicted results against the test and numerical results.

\section{The Adopted Methodology}

One of the primary objectives of the present study is to develop recommendations for evaluating the bending moment resistance of ML-CFST beams in accordance with the unified theory. The adopted formula (Equation (1)) depends on the flexural strength index $\left(\gamma_{\mathrm{m}}\right)$ and the compressive strength $\left(\mathrm{f}_{\mathrm{sc}}\right)$ of a composite section. Adequate formulas for calculating $\gamma_{\mathrm{m}}$ and $\mathrm{f}_{\mathrm{sc}}$ for the studied ML-CFST beams are proposed. The adopted methodology is illustrated in Figure 2.

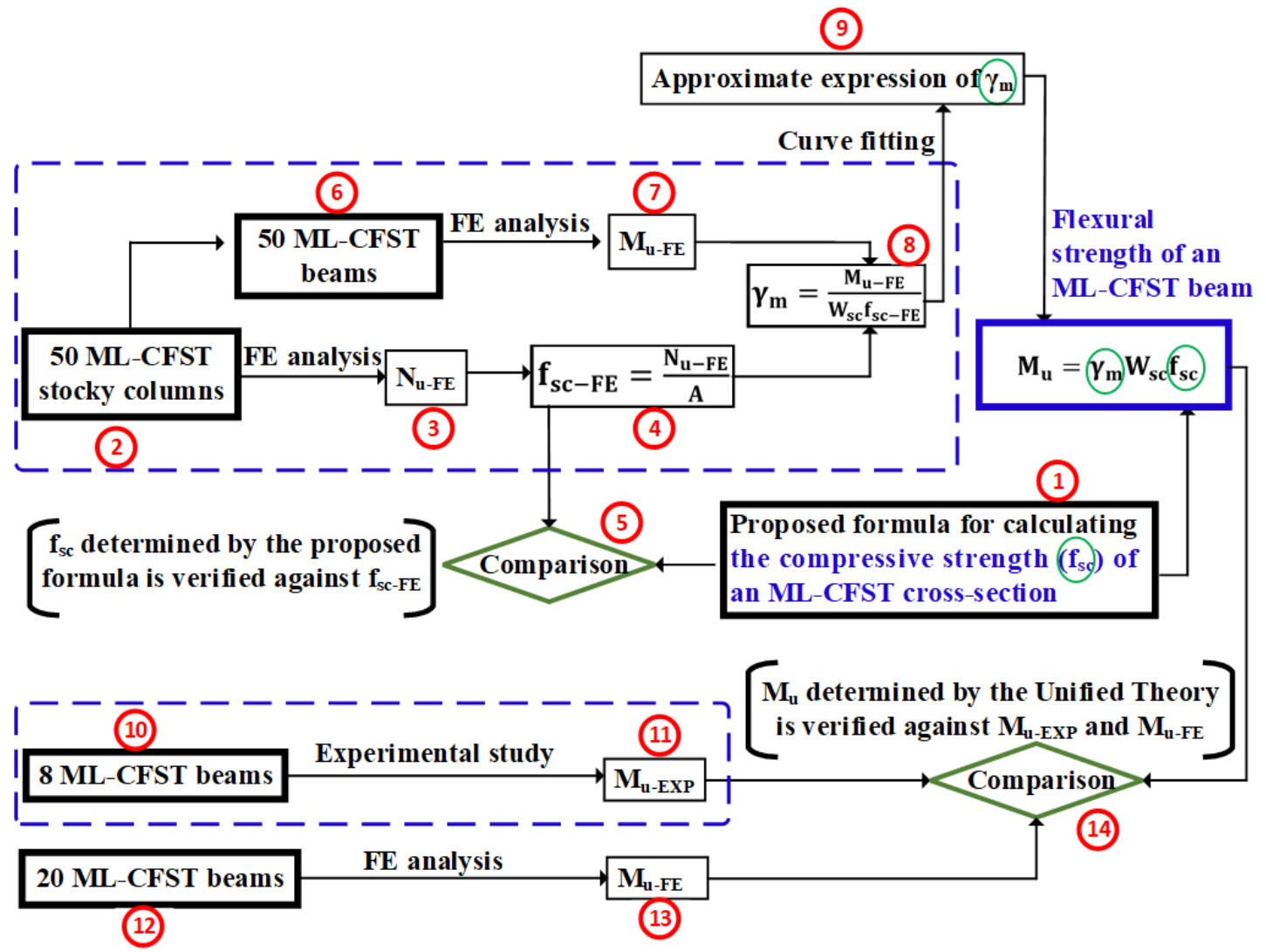

Figure 2. Illustration of the adopted methodology.

First, an adequate formula for calculating $\mathrm{f}_{\mathrm{sc}}$ for ML-CFST sections is proposed (1) of Figure 2). FE analyses of 50 ML-CFST stub columns over a wider range of cross-sectional dimensions and material properties were performed to obtain the ultimate axial loads $\left(\mathrm{N}_{\mathrm{u}-\mathrm{FE}}\right.$ ) (2) and (3). $\mathrm{N}_{\mathrm{u}-\mathrm{FE}}$ divided by the whole cross-section area (A) is equal to the compressive strength $\left(f_{\mathrm{sc}}\right)$ of the composite section (4)). The accuracy of the proposed formula was assessed based on the numerical results of finite element (FE) analyses (5). 
Secondly, on the basis of FE models of 50-stub columns, FE models of 50 ML-CFST beams with varied loading conditions and spans were generated (6). Numerical analysis was then carried out, and the ultimate bending moments $\left(\mathrm{M}_{\mathrm{u}-\mathrm{FE}}\right)$ were obtained (7) $)$. The adopted approach to determine the $\mathrm{M}_{\mathrm{u}-\mathrm{FE}}$ of ML-CFST beams is shown in Section 6.3 of the present paper. According to Equation (1), $\gamma_{\mathrm{m}}$ is equal to the ratio of $\mathrm{M}_{\mathrm{u}-\mathrm{FE}} /\left(\mathrm{W}_{\mathrm{sc}} \mathrm{f}_{\mathrm{sc}-\mathrm{FE}}\right)$ (8)). For the ML-CFST sections, $\mathrm{W}_{\mathrm{sc}}$ is equal to the ratio of $I / y$, where $I$ is the area moment of inertia and $y$ is the distance from the neutral axis to the extreme compression fiber. The approximate expression of $\gamma_{\mathrm{m}}$ was then developed by fitting the variables to the numerical results (9)).

Lastly, an experimental study on 8 specimens was conducted to investigate the flexural performance of the ML-CFST beams (10 and (1D). To generate further data on the bending moment resistance of ML-CFST beams, 20 ML-CFST FE beams with varied cross-sectional dimensions and material properties were analyzed (12 and 13). The predicted results by the proposed approach were compared against the test results and numerical results (14).

\section{Compressive Strength $\left(\mathrm{f}_{\mathrm{sc}}\right)$ of an ML-CFST Section}

\section{1. $f_{\text {sc }}$ for Conventional CFST Sections}

A formula in line with the unified theory for determining the compressive strength $\left(f_{s c}\right)$ of a conventional CFST beam is provided in GB 50936-2014 [13]. It is only applicable to circular and regular polygon (square, octagon, and hexadecagon) CFST sections and is given by

$$
\begin{gathered}
\mathrm{f}_{\mathrm{sc}}=\left(1.212+\mathrm{B} \xi+C \xi^{2}\right) \mathrm{f}_{\mathrm{c}}^{\prime} \\
\xi=\frac{\mathrm{A}_{\mathrm{s}} \mathrm{f}_{\mathrm{y}}}{\mathrm{A}_{\mathrm{c}} \mathrm{f}_{\mathrm{c}}^{\prime}}
\end{gathered}
$$

where $A_{s}$ and $A_{c}$ are the areas of steel and concrete, respectively, $f_{c}^{\prime}$ is the compressive strength (prism) of concrete, $f_{y}$ is the yield strength of the steel tube, and coefficients $B$ and $\mathrm{C}$ consider the contributions of steel and concrete, respectively, and are only applicable to circular and regular polygon CFST sections. $B$ and $C$ for square CFST sections are given by

$$
\begin{aligned}
& \mathrm{B}=0.131 \frac{\mathrm{f}_{\mathrm{y}}}{213}+0.723 \\
& \mathrm{C}=-0.7 \frac{\mathrm{f}_{\mathrm{c}}^{\prime}}{14.4}+0.026
\end{aligned}
$$

Factor $\xi$, originally proposed by Zhong [14], is intended to account for the confinement effect on infill concrete for CFST members with circular sections. It does not take into consideration the cross-section geometry, which may have a significant influence on the confinement.

\subsection{Proposed $f_{s c}$ Applicable to ML-CFST Sections}

An adequate formula in accordance with the unified theory was proposed in the present study to calculate the compressive strength of an ML-CFST section. The development of the formula generally included two aspects:

- $\quad$ Each cell of an ML-CFST cross-section was equated with a single square CFST section by introducing an equivalent shape factor $\left(\mathrm{K}_{\text {equi }}\right)$ that considered the influence of the geometry and boundary conditions of the cell;

- The compression resistance ( $\mathrm{f}_{\mathrm{sc}}$ multiplied by the cross-sectional area) of an ML-CFST cross-section was taken as a linear superposition of the compression resistance of its three cells.

The procedure for developing the formula for calculating the compressive strength of an ML-CFST section is illustrated in Figure 3. 


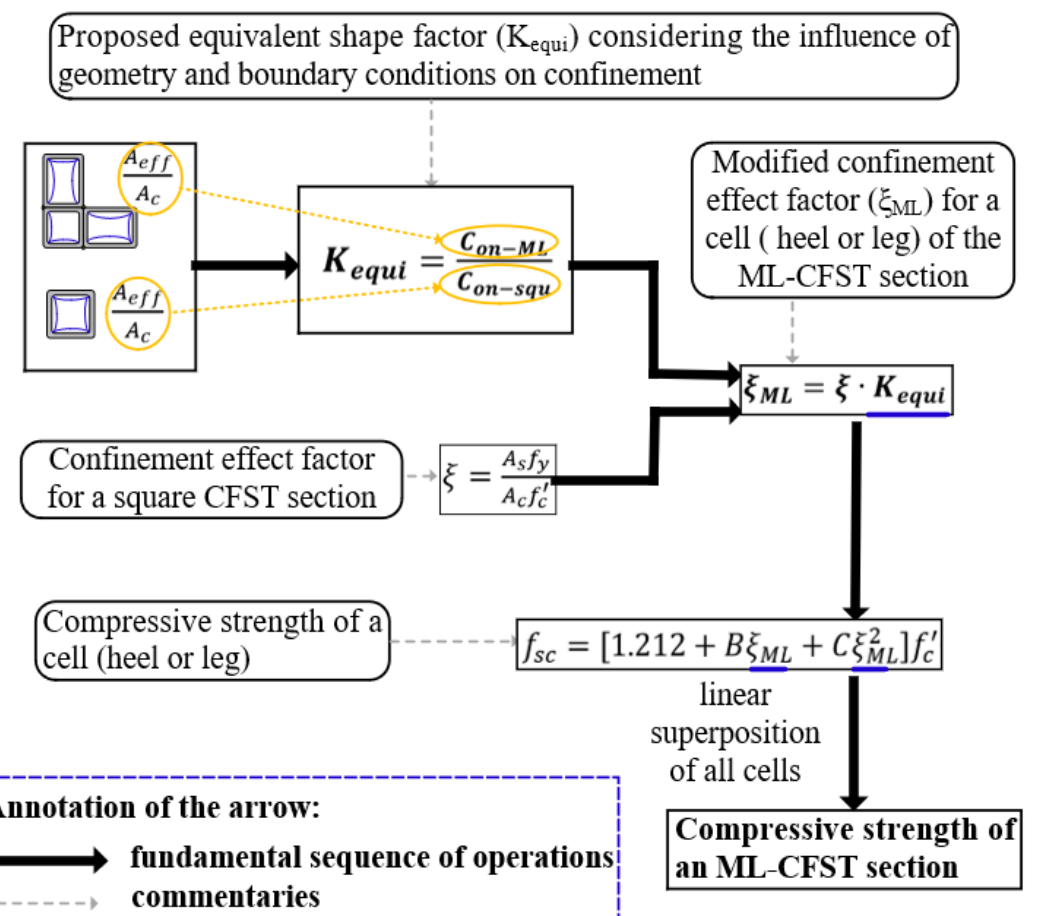

Figure 3. The development of a formula applicable to determining the compressive strength $\left(\mathrm{f}_{\mathrm{sc}}\right)$ of an ML-CFST section.

First, the ML-CFST cross-section was divided into a highly confined area and a less confined area based on the research findings of Lin and Teng [23], Megalooikonomou and Papavasileiou [24], and Zuo et al. [25], as illustrated in Figure 4. The boundary between the two areas was a second-degree parabola with an initial tangent angle of $\theta$. The adopted approach is similar to the one presented by Shen and Tu [22]. Compared with the concrete in a less confined area, the concrete in a highly confined area received much greater confining stresses that were produced by the steel tube due to the dilation of the infill concrete.

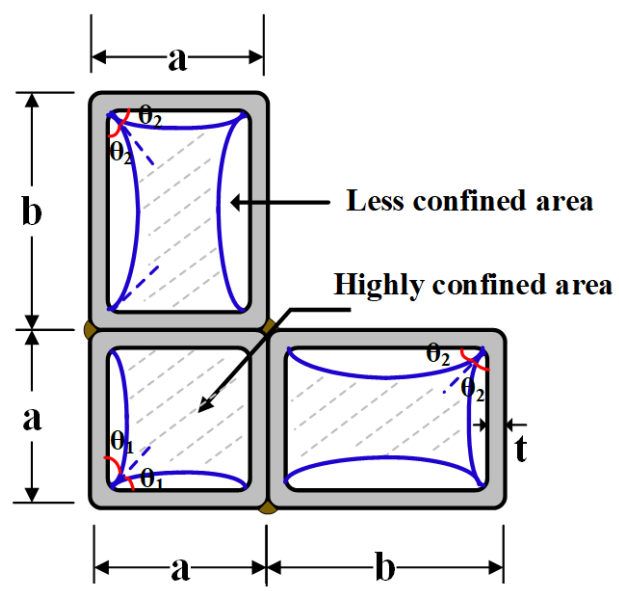

(a)

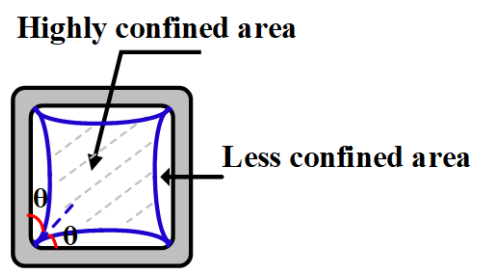

(b)

Figure 4. Highly confined areas and less confined areas for (a) an ML-CFST section and (b) a square section.

Secondly, the confinement ratio factor $\left(\mathrm{C}_{\mathrm{on}}\right)$ was defined as

$$
\mathrm{C}_{\mathrm{on}}=\frac{\mathrm{A}_{\mathrm{eff}}}{\mathrm{A}_{\mathrm{c}}}
$$


where $\mathrm{A}_{\text {eff }}$ and $\mathrm{A}_{\mathrm{c}}$ are the highly confined concrete area and the total concrete area, respectively.

$\mathrm{C}_{\text {on }}$ for different cells of an ML-CFST section was then given by

$$
\mathrm{C}_{\text {on-ML-Squ }} \approx 1-\frac{1}{3} \tan \theta_{1} \text { for the square cell }
$$

$\mathrm{C}_{\text {on-ML-Rect }} \approx 1-\frac{\mathrm{a}-2 \mathrm{t}}{6(\mathrm{~b}-2 \mathrm{t})} \tan \theta_{2}-\frac{\mathrm{b}-2 \mathrm{t}}{3(\mathrm{a}-2 \mathrm{t})} \tan \theta_{2}$ for the two identical rectangular cells

where $\theta_{1}=45^{\circ}, \theta_{2}=\min \left\{180^{\circ} / \pi \cdot \arctan [(\mathrm{a}-2 \mathrm{t}) /(\mathrm{b}-2 \mathrm{t})], 45^{\circ}\right\}$, and $\mathrm{C}_{\text {on-ML-Squ }}$ and $\mathrm{C}_{\mathrm{on}-\mathrm{ML}-\mathrm{Rect}}$ are the confinement ratio factors for the square cell (the heel component) and the two identical rectangular (squares are considered special cases of rectangles here) steel cells that stick out over the heel component, respectively. Note that the round corners of the square and rectangular cells were assumed to be sharp to simplify the calculation work.

Third, the equivalent shape factor $\left(\mathrm{K}_{\text {equi }}\right)$ was taken as the confinement ratio of a cell divided by the confinement ratio of a single square counterpart (as shown in Figure $4 \mathrm{~b}$ ). For a given confinement ratio, the enhancement effect generated from the steel tube was considered to be affected by the geometry and boundary condition of the cell. $\mathrm{K}_{\text {equi }}$ was given by

$$
\begin{gathered}
\mathrm{k}_{\text {equi-Squ }}=\frac{\mathrm{C}_{\text {on-ML-Heel }}}{\mathrm{C}_{\text {on-squ }}} \text { for the square cell } \\
\mathrm{k}_{\text {equi-Rect }}=\frac{\mathrm{C}_{\text {on-ML-Leg }}}{\mathrm{C}_{\text {on-squ }}} \text { for the two identical rectangular cells }
\end{gathered}
$$

where the confinement ratio ( $\mathrm{C}_{\text {on-s-squ }}$ ) of a single square section was given by

$$
\mathrm{C}_{\text {on-s-Squ }}=1-\frac{2}{3} \tan \theta
$$

where $\theta$ is equal to $\theta_{1}$ for $k_{\text {equi-Squ }}$ and $\theta_{2}$ for $k_{\text {equi-Rect }}$. It should be noted that the confinement ratio of a square cell of the ML-CFST section was greater than that of a single square counterpart, as the former had a more effectively confined area that benefitted from its boundary conditions.

Lastly, the compression resistance of an ML-CFST cross-section was taken as a linear superposition of the compression resistance of its three components, as given by

$$
\mathrm{Af}_{\mathrm{sc}}=\mathrm{A}_{\mathrm{Squ}} \mathrm{f}_{\mathrm{sc}-\mathrm{Squ}}+\mathrm{A}_{\text {Rect }} \mathrm{f}_{\mathrm{sc}-\text { Rect }}
$$

Rewriting Equation (12) gives

$$
f_{s c}=\frac{A_{S q u} f_{\text {sc-Squ }}+A_{\text {Rect }} f_{\text {sc-Rect }}}{A_{\text {Heel }}+A_{\text {Leg }}}
$$

where $\mathrm{A}$ is the area of the whole section, $\mathrm{A}_{\mathrm{Squ}}$ and $\mathrm{A}_{\text {Rect }}$ are the areas of the heel component (square cell) and the overhanging components (two identical rectangular or square cells), respectively, and $\mathrm{A}=\mathrm{A}_{\mathrm{Squ}}+\mathrm{A}_{\text {Rect }}$.

By introducing the equivalent shape factor $k_{\text {equi, }}$, the confinement effect factor $(\xi)$ in Equation (2) was substituted by the modified confinement effect factor $\left(\xi_{M}\right)$, in which $\xi_{\mathrm{M}}=\mathrm{k}_{\text {equi }} \xi$. For an ML-CFST section, $\mathrm{f}_{\mathrm{sc}-S q u}$ and $\mathrm{f}_{\mathrm{sc}-\text { Rect }}$ are given by

$$
\begin{gathered}
\mathrm{f}_{\text {sc-Squ }}=\left[1.212+B \xi_{M-\text { Squ }}+C\left(\xi_{\text {M-Squ }}\right)^{2}\right] \mathrm{f}_{\mathrm{c}}^{\prime} \\
\mathrm{f}_{\text {sc-Rect }}=\left[1.212+B \xi_{M-\text { Rect }}+C\left(\xi_{M-\text { Rect }}\right)^{2}\right] \mathrm{f}_{\mathrm{C}}^{\prime} \\
\xi_{\text {M-Squ }}=k_{\text {equi-Squ }} \xi
\end{gathered}
$$




$$
\xi_{\mathrm{M}-\text { Rect }}=\mathrm{k}_{\text {equi-Rect }} \xi
$$

where coefficients B and C are determined by Equations (4) and (5), respectively.

Substituting Equations (14) and (15) into Equation (13) gives

$$
\mathrm{f}_{\mathrm{sc}}=\left[1.212+\frac{\mathrm{B}\left(\mathrm{A}_{\mathrm{Squ}} \xi_{\mathrm{M}-\mathrm{Squ}}+\mathrm{A}_{\text {Rect }} \xi_{\mathrm{M}-\text { Rect }}\right)}{\mathrm{A}_{\mathrm{Squ}}+\mathrm{A}_{\text {Rect }}}+\frac{\mathrm{C}\left(\mathrm{A}_{\mathrm{Squ}} \xi_{\mathrm{M}-\mathrm{Squ}}{ }^{2}+\mathrm{A}_{\text {Rect }} \xi_{\mathrm{M}-\text { Rect }}{ }^{2}\right)}{\mathrm{A}_{\mathrm{Squ}}+\mathrm{A}_{\text {Rect }}}\right] \mathrm{f}_{\mathrm{C}}^{\prime}
$$

\section{Verification of the Proposed $f_{s c}$}

\subsection{Development and Validation of FE Models for ML-CFST Stub Columns}

The general purpose finite element (FE) analyzer Abaqus/Standard (6.13) was employed to conduct numerical analysis of the ML-CFST beams. The shell element (S4R) and the solid element (C3D8R) were used to model the steel tubes and the infill concrete, respectively. For the definition of the contact properties between the steel tube and infill concrete, tangential behavior was dictated by a "penalty" friction formulation, while normal behavior obeyed a "hard contact" function with the default constraint enforcement method. The interaction between steel tubes was modeled by a "tie constraint". Based on previous mesh convergence studies, a suitable mesh size was chosen. The idealized fourstage stress-strain curve provided in [26] was used for the steel material. The multi-axial stress states of the steel followed "Plastic Flow" rules and the "Von Mises" yield criterion. The concrete-damaged plasticity model [27], in which the failure of the concrete was caused by cracking due to tensile stress and crushing due to compressive stress, was employed. The two-stage stress-strain curve originally proposed by Han et al. [28] was adopted to model the structural behavior of the infill concrete. It was given by

$$
\frac{\sigma}{\mathrm{f}_{\mathrm{c}}^{\prime}}=\left\{\begin{array}{cc}
2 \frac{\varepsilon}{\varepsilon_{0}}-\left(\frac{\varepsilon}{\varepsilon_{0}}\right)^{2} & \text { for } \frac{\varepsilon}{\varepsilon_{0}} \leq 1 \\
\frac{\frac{\varepsilon}{\varepsilon_{0}}}{\beta\left(\frac{\varepsilon}{\varepsilon_{0}}-1\right)^{n}+\frac{\varepsilon}{\varepsilon_{0}}} & \text { for } \frac{\varepsilon}{\varepsilon_{0}}>1
\end{array}\right.
$$

where $\sigma$ and $\varepsilon$ represent the concrete's stress and strain, respectively, $\mathrm{f}_{\mathrm{c}}^{\prime}$ denotes the compressive strength (prism) of the concrete; $\varepsilon_{0}=\left(1300+12.5 \mathrm{f}_{\mathrm{c}}^{\prime}+800 \xi^{0.2}\right) \times 10^{-6}, \eta=1.5 \varepsilon_{0} / \varepsilon+1.6$, $\beta=\left(f_{c}^{\prime}\right)^{0.1} /\left[1.2 \times(1+\xi)^{0.5}\right]$, and $\xi$ denotes the confinement effect factor. The ascending branch $\left(\varepsilon / \varepsilon_{0} \leq 1\right)$ of this stress-strain curve is similar to that for the plain concrete suggested by Hognested et al. [29], while the descending branch $\left(\varepsilon / \varepsilon_{0}>1\right)$ of the curve is influenced by the confinement effect factor. To consider the influence of the cross-sectional geometry on the confinement, the factor $\xi$ adopted in the stress-strain curve was substituted with $\xi\left(\mathrm{K}_{\text {equi-Squ }}+\mathrm{K}_{\text {equi-Rect }}\right) / 2$.

Considering the limited experimental data on ML-CFST stub columns, the developed FE models were validated against available test results for nine ML-CFST stub columns subjected to biaxial eccentric compression reported in [10]. For the validation study, the material properties were modeled similar to those reported in [10], where the average yield strength $\left(f_{\mathrm{y}}\right)$ and Young's modulus of steel $\left(\mathrm{E}_{\mathrm{s}}\right)$ were $343.2 \mathrm{MPa}$ and $202.7 \mathrm{GPa}$, respectively, while the average compressive strength $\left(\mathrm{f}_{\mathrm{c}}^{\prime}\right.$, prism) and average Young's modulus $\left(\mathrm{E}_{\mathrm{c}}\right)$ of the infill concrete were $35.7 \mathrm{MPa}$ and $34.5 \mathrm{GPa}$, respectively. All the ML-CFST stub columns had the same nominal cross-sectional dimension $(\mathrm{a} \times \mathrm{b} \times \mathrm{t}=60 \mathrm{~mm} \times 100 \mathrm{~mm} \times 2.5 \mathrm{~mm})$, where $a$ and $b$ represent the nominal side length of the cell and $t$ is the nominal wall thickness of the steel tube. All the ML-CFST stub columns had a length of $480 \mathrm{~mm}$. Figure 5 shows a comparison of the predicted results determined by the FE models against the experimental results. In this, $\mathrm{N}_{\mathrm{u}-\exp }$ and $\mathrm{N}_{\mathrm{u}-\mathrm{FE}}$ denote the ultimate vertical load obtained from the test and FE analysis, respectively, $\mu$ is the mean value, and COV denotes coefficients of variation. It was found that the mean value of the $\mathrm{N}_{\mathrm{u}-\exp } / \mathrm{N}_{\mathrm{u}-\mathrm{FE}}$ ratios was 0.97 , and the corresponding COV was 0.05. The differences between $\mathrm{N}_{\mathrm{u}-\exp }$ and $\mathrm{N}_{\mathrm{u}-\mathrm{FE}}$ were all within $9 \%$. The results indicated that the developed FE models were capable of accurately predicting the ultimate capacities of the ML-CFST stub columns. 


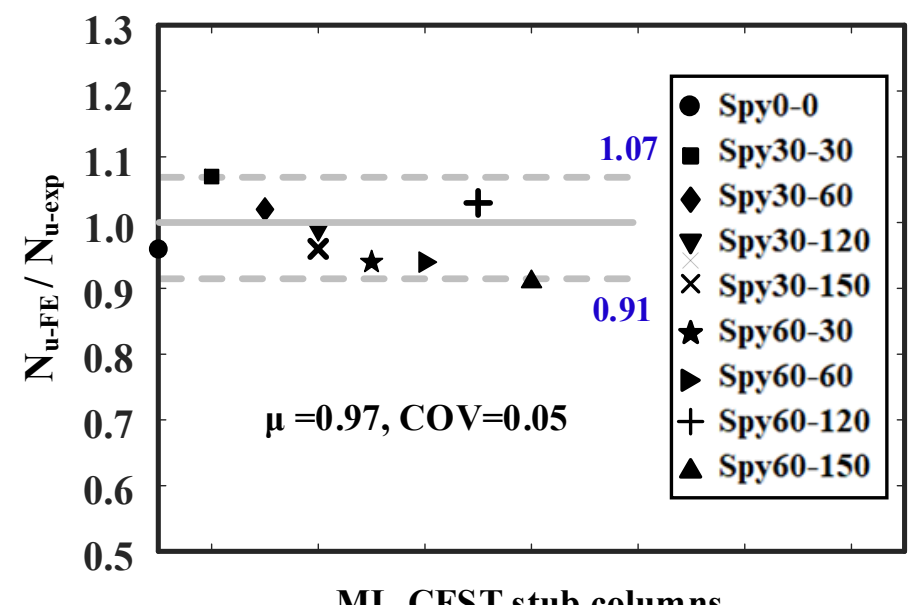

Figure 5. A comparison of the numerical results against the experimental results for the nine ML-CFST stub columns reported in [10].

\subsection{Comparison of the Proposed $f_{s c}$ against Numerical Results}

Upon the validation study, the numerical analysis of 50 ML-CFST stub columns over a wider range of cross-sectional dimensions and material properties was performed to generate further numerical results. The parameters of the FE models were designed to be reasonably discrete in order to ensure the precision of the generated numerical data, in which $(\mathrm{a}+\mathrm{b}) / \mathrm{a}=2.0,2.2,2.5,2.7,2.8$, and $3.0 ; \mathrm{t}=2,2.5,3,4,4.5$, and $6 \mathrm{~mm} ; \mathrm{f}_{\mathrm{y}}=250,300$, $370,450,500$, and $600 \mathrm{MPa}$; and $\mathrm{f}_{\mathrm{c}}^{\prime}=30,45,55,65$, and $80 \mathrm{MPa}$. The details of the developed FE models are shown in Table A1 of Appendix A. All the stub column models were capable of reaching full cross-sectional plastification.

A comparison of the compressive strength $\left(\mathrm{f}_{\mathrm{sc}}\right)$ determined by the proposed formula against the numerical results from 50 FE models is shown in Figure 6. Detailed results for $\mathrm{f}_{\mathrm{sc}-\mathrm{uni}} / \mathrm{f}_{\mathrm{sc}-\mathrm{FE}}, \varepsilon+, \varepsilon-, \mu$, and COV are shown in Table A1 of Appendix A. In this, $\mathrm{f}_{\mathrm{sc}-\text { uni }}$ and $\mathrm{f}_{\mathrm{sc}-\mathrm{FE}}$ denote the compressive strength determined by the proposed formula and FE analysis, respectively, while $\varepsilon+$ and $\varepsilon$ - represent the maximum overestimation error and the maximum underestimation error, respectively. From the table, the mean value of the ratios of $\mathrm{f}_{\mathrm{sc}-\mathrm{uni}} / \mathrm{f}_{\mathrm{sc}-\mathrm{FE}}$ for the 50 models was 0.96 , while the COV was 0.09 , which showed that the results predicted by the proposed formula were in close agreement with the numerical results. It can be seen that the conservative error was no more than $19 \%$, while the unconservative error was within $12 \%$ (still at a low to reasonable level). The above results indicated that the proposed formula for calculating $\mathrm{f}_{\mathrm{sc}}$ provided reasonably accurate results for the ML-CFST sections.

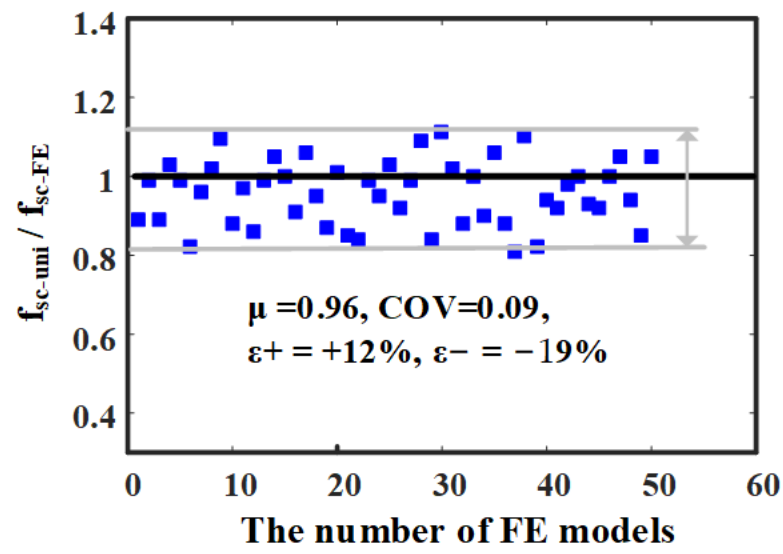

Figure 6. Comparison of the compressive strength $\left(f_{\mathrm{sc}}\right)$ determined by the proposed formula against the numerical results from FE stub column models. 


\section{Flexural Strength Index $\left(\gamma_{\mathrm{m}}\right)$}

\subsection{Development and Validation of FE Models for ML-CFST Beams}

ML-CFST beam models were generated by extending the length and changing the loading conditions of the corresponding ML-CFST stub column models. All the models were designed to avoid the occurrence of lateral torsional buckling and shear failure. The accuracy of the created FE models was assessed based on the experimental results of eight ML-CFST beams presented in Section 6 of this paper. For the validation study of the FE models, the stress-strain curves and key material parameters obtained from material tests were used. A comparison of the moment-deflection curves determined by the developed FE models against the experimental results for the eight ML-CFST beams is shown in Figure 7. The close agreement between the predicted results and the test results indicated that the developed FE models were capable of accurately replicating the flexural response of ML-CFST beams.

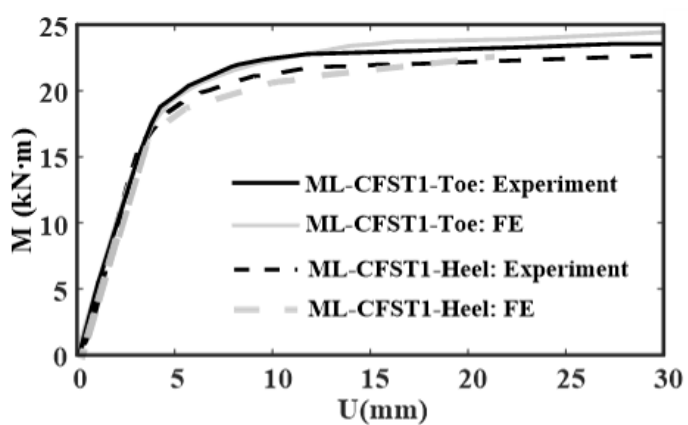

(a) ML-CFST1

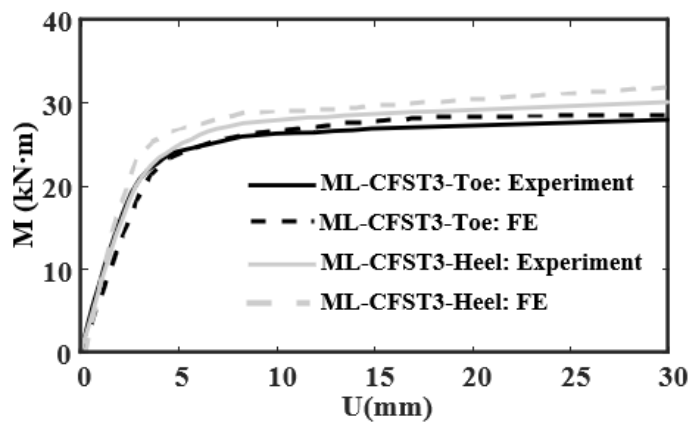

(c) ML-CFST3

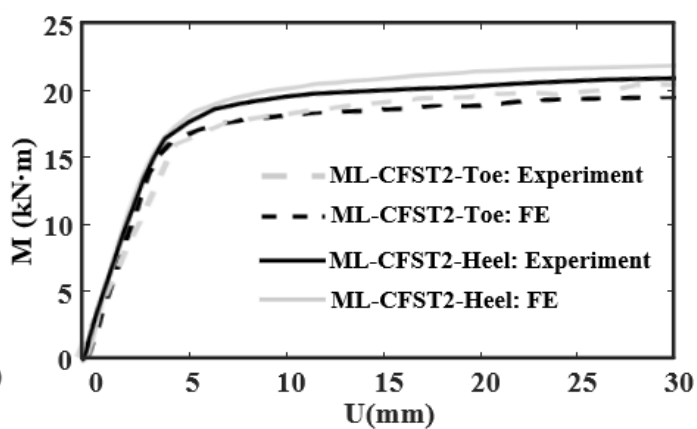

(b) ML-CFST2

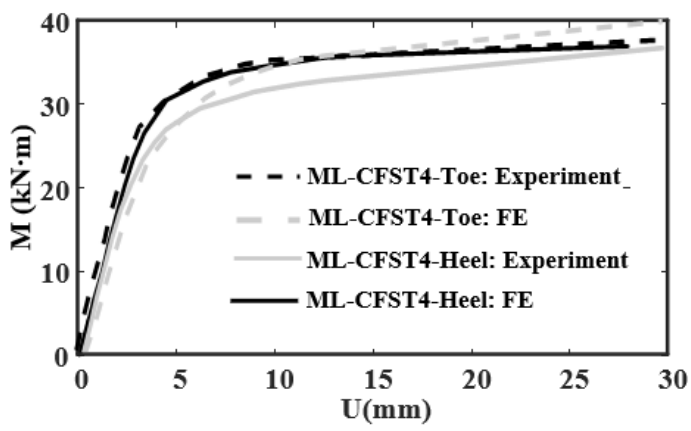

(d) ML-CFST4

Figure 7. Comparison of moment-deflection curves from FE models against test results for ML-CFST beams: (a) ML-CFST1; (b) ML-CFST2; (c) ML-CFST3; (d) ML-CFST4.

\subsection{Approximate Expression of $\gamma_{m}$}

Upon the above validation study, numerical analyses of 50 ML-CFST beams were carried out. The adopted length-to-section-depth ratios $(\mathrm{L} /(\mathrm{a}+\mathrm{b}))$ were equal to $7,9,10$, and 12. The ultimate bending moments $\left(\mathrm{M}_{\mathrm{u}-\mathrm{FE}}\right)$ of these beams were then obtained. By rewriting Equation (1), the flexural strength factor $\left(\gamma_{\mathrm{m}}\right)$ was equal to the ratio of $\mathrm{M}_{\mathrm{u}-\mathrm{FE}} /\left(\mathrm{W}_{\mathrm{sc}} \mathrm{f}_{\mathrm{sc}-\mathrm{FE}}\right)$, in which $\mathrm{W}_{\mathrm{sc}}$ is the section modulus (corresponding to the extreme compression fiber) and $\mathrm{f}_{\mathrm{sc}-\mathrm{FE}}$ is the compressive strength of the corresponding ML-CFST stub column model. Detailed values of $\gamma_{\mathrm{m}}$ for all 50 ML-CFST beams are shown in Table A1 of Appendix A.

The approximate expression of $\gamma_{\mathrm{m}}$ was developed by fitting relevant variables to the numerical results. It was found that, for an ML-CFST beam with the given cross-section, $\gamma_{\mathrm{m}}$ depended heavily on the confinement effect factor $(\xi)$ and the approximate equivalent shape factor $\left(\mathrm{K}_{\text {equi-av }}\right)$, where $\mathrm{K}_{\text {equi-av }}$ is equal to $\left(\mathrm{K}_{\text {equi-Squ }}+\mathrm{K}_{\text {equi-Rect }}\right) / 2$. This was similar to the research findings of Han [15] for regular CFST beams. Han [15] suggested that the expression of $\gamma_{\mathrm{m}}$ was a function relating to the variable of the confinement effect factor, 
and it was adopted in GB 50936-2014 [14]. Based on regression analysis, the developed approximate expression of $\gamma_{\mathrm{m}}$ is given by

$$
\begin{gathered}
\gamma_{\mathrm{m}}=0.3+2.6 \ln \left[0.4+\xi \mathrm{K}_{\text {equi-av }}\right] \\
\mathrm{K}_{\text {equi-av }}=\frac{\mathrm{K}_{\text {equi-Squ }}+\mathrm{K}_{\text {equi-Rect }}}{2}
\end{gathered}
$$

A plot of $\gamma_{\mathrm{m}}$ versus $\xi \mathrm{K}_{\text {equi-av }}$ for the studied ML-CFST beams is shown in Figure 8.

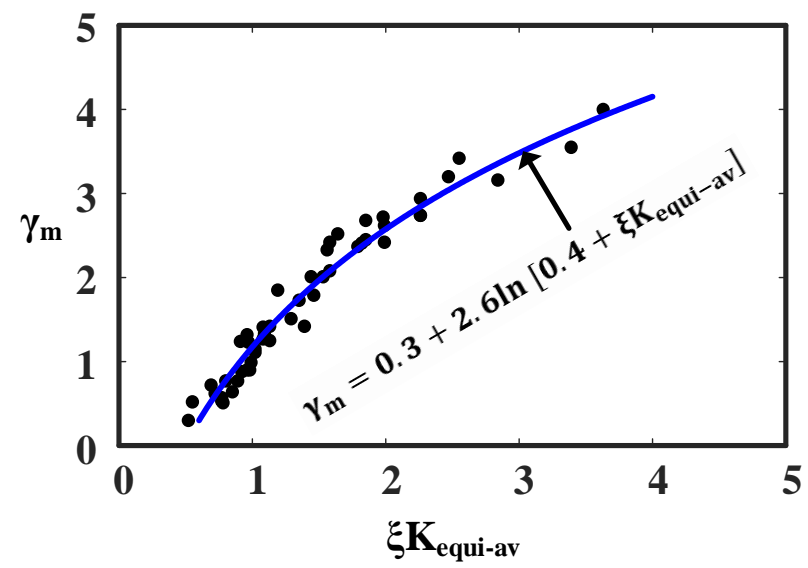

Figure 8. $\gamma_{\mathrm{m}}$ versus $\xi \mathrm{K}_{\text {equi-av }}$ for ML-CFST beams.

\section{Experimental Study}

\subsection{Description of Specimens}

The ML-CFST beams were designed to be capable of developing their full plastic bending moments without lateral torsional buckling or local buckling. Figure 9 shows the cross-section parameters $\left(a, b, t\right.$, and $\left.R_{-i n}\right)$, where $a$ and $b$ represent the width and height of the two identical rectangular cells sticking out over the heel component, respectively; $a$ is also the side length of the square cell in the heel component; and $(a+b) / a$ is the depth-to-width ratio of the legs of the composite L-section. The character $\mathrm{R}_{\text {-in }}$ denotes the inside radius of the corner, and $t$ is the wall thickness of the steel tube. The major principal axis (the strongest axis) of the composite section is the symmetrical axis that passes through the centroid, while the centroidal axis perpendicular to the major principal axis is termed the minor principal axis (the weakest axis).

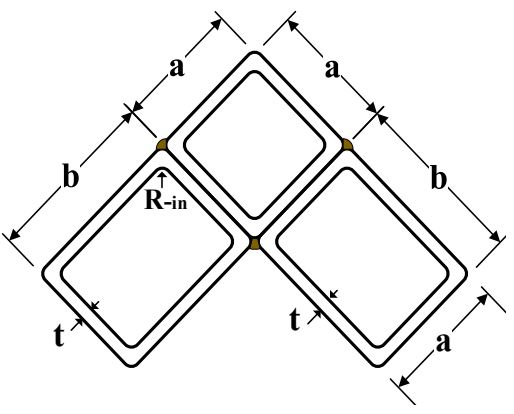

Figure 9. Definition of the cross-section parameter.

A total of eight ML-CFST specimens were tested. All specimens bent about the minor principal axis in the present study. Table 1 shows the details about the specimens' geometric and material properties. The specimens were divided into four groups. Two identical specimens that had the same material and geometric properties were prepared for each group, in which vertical concentrated loads were applied to the toes (two tips of the legs) of the L-section for one specimen and the heel of the L-section for the other specimen. The 
symbols "Toe" and "Heel" in the specimen's name correspond to the load applied to the toes and heel, respectively.

Table 1. Geometric and material properties of the test ML-CFST beams.

\begin{tabular}{|c|c|c|c|c|c|c|c|c|c|c|c|}
\hline Specimen & $\begin{array}{c}a \\
(\mathrm{~mm})\end{array}$ & $\begin{array}{c}b \\
(\mathrm{~mm})\end{array}$ & $\mathrm{t}(\mathrm{mm})$ & $\begin{array}{l}R_{\text {-in }} \\
(\mathbf{m m})\end{array}$ & $\begin{array}{c}\mathrm{L}_{\mathrm{n}} \\
(\mathrm{mm})\end{array}$ & $\begin{array}{l}\text { (b+ } \\
\text { a)/a }\end{array}$ & $\begin{array}{c}E_{s} \\
(\mathrm{GPa})\end{array}$ & $\begin{array}{c}\mathbf{f}_{\mathbf{y}} \\
(\mathbf{M P a})\end{array}$ & $\begin{array}{c}E_{c} \\
(\mathrm{GPa})\end{array}$ & $\begin{array}{c}\mathrm{f}_{\mathrm{c}} \\
(\mathrm{MPa})\end{array}$ & $\mathbf{M}_{\mathbf{u}-\exp }$ \\
\hline ML-CFST1-Heel & 60.2 & 60.1 & 2.50 & 4.00 & 1301.0 & 2.0 & 199.7 & 298.1 & 36.3 & 42.2 & 22.8 \\
\hline ML-CFST1-Toe & 59.7 & 60.0 & 2.51 & 4.77 & 1300.7 & 2.0 & 199.7 & 298.1 & 36.3 & 42.2 & 23.9 \\
\hline ML-CFST2-Heel & 59.9 & 79.5 & 2.03 & 3.25 & 1300.2 & 2.3 & 197.5 & 306.0 & 36.3 & 42.2 & 21.9 \\
\hline ML-CFST2-Toe & 60.1 & 80.0 & 2.00 & 3.80 & 1299.8 & 2.3 & 197.5 & 306.0 & 36.3 & 42.2 & 21.4 \\
\hline ML-CFST3-Heel & 60.0 & 80.1 & 2.50 & 4.51 & 1300.1 & 2.3 & 199.7 & 298.1 & 36.3 & 42.2 & 29.4 \\
\hline ML-CFST3-Toe & 60.4 & 79.9 & 2.49 & 4.73 & 1300.0 & 2.3 & 199.7 & 298.1 & 36.3 & 42.2 & 28.0 \\
\hline ML-CFST4-Heel & 60.2 & 100.5 & 2.52 & 4.03 & 1300.7 & 2.7 & 199.7 & 298.1 & 36.3 & 42.2 & 36.2 \\
\hline ML-CFST4-Toe & 60.0 & 100.3 & 2.50 & 4.75 & 1301.1 & 2.7 & 199.7 & 298.1 & 36.3 & 42.2 & 38.3 \\
\hline
\end{tabular}

The depth-to-width ratios $((a+b) / a)$ of the section leg were 2.0, 2.3, 2.3, and 2.7 for the first, second, third, and fourth group, respectively. The nominal wall thickness of the steel tubes was $2.0 \mathrm{~mm}$ for the second group and $2.5 \mathrm{~mm}$ for the other groups. All specimens had a nominal length $\left(\mathrm{L}_{\mathrm{n}}\right)$ of $1300 \mathrm{~mm}$. For the steel tubes with a nominal wall thickness of $2.50 \mathrm{~mm}$, the average values of $\mathrm{f}_{\mathrm{y}}$ and $\mathrm{E}_{\mathrm{s}}$ were $298.1 \mathrm{MPa}$ and $199.7 \mathrm{GPa}$, respectively, while the average values of $\mathrm{f}_{\mathrm{y}}$ and $\mathrm{E}_{\mathrm{S}}$ for the other steel tubes were $306.0 \mathrm{MPa}$ and $197.5 \mathrm{GPa}$, respectively. For all the ML-CFST specimens, the average compressive strength $\left(f_{c}^{\prime}\right.$, prism) and average Young's modulus $\left(E_{c}\right)$ of the infill concrete were $42.2 \mathrm{MPa}$ and 36.3 GPa, respectively.

\subsection{Description of the Test Set-Up}

A series of four-point bending tests on ML-CFST beams were carried out. The MLCFST beam was simply supported with a span of $1200 \mathrm{~mm}$. Special steel blocks were manufactured in advance to ensure that the loading process was feasible. They were placed on the two symmetrical loading points and two supports (pinned and roller) as shown in Figure 10. The gap between the roller and the steel plate at the roller support was filled with sand to prevent the roller from moving.

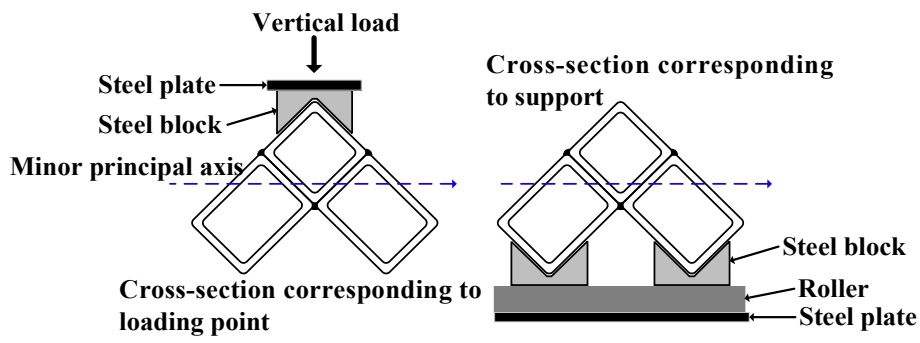

(a)

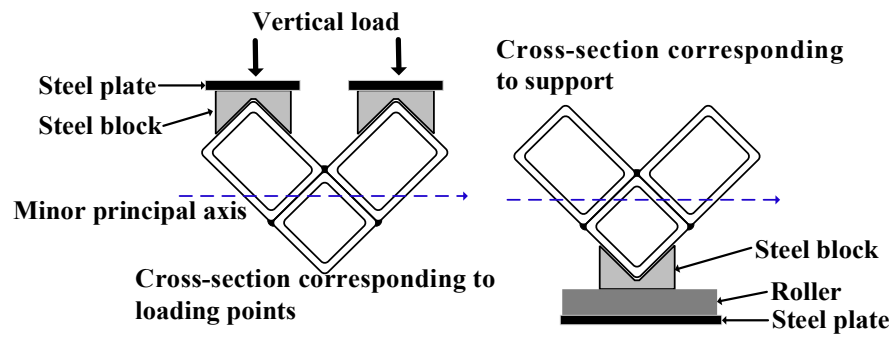

(b)

Figure 10. Cross-section corresponding to loading points and supports: (a) Load at the heel; (b) Load at the toes. 
An overall view of the four-point bending test is shown in Figure 11. Two linear variable displacement transducers (LVDTs) were installed to measure the vertical displacements at the two loading points, while one LVDT was placed to record the vertical displacements at the mid-span of the specimen. Another two LVDTs, located at both ends of the specimen, were used to measure the rotations during the loading process.

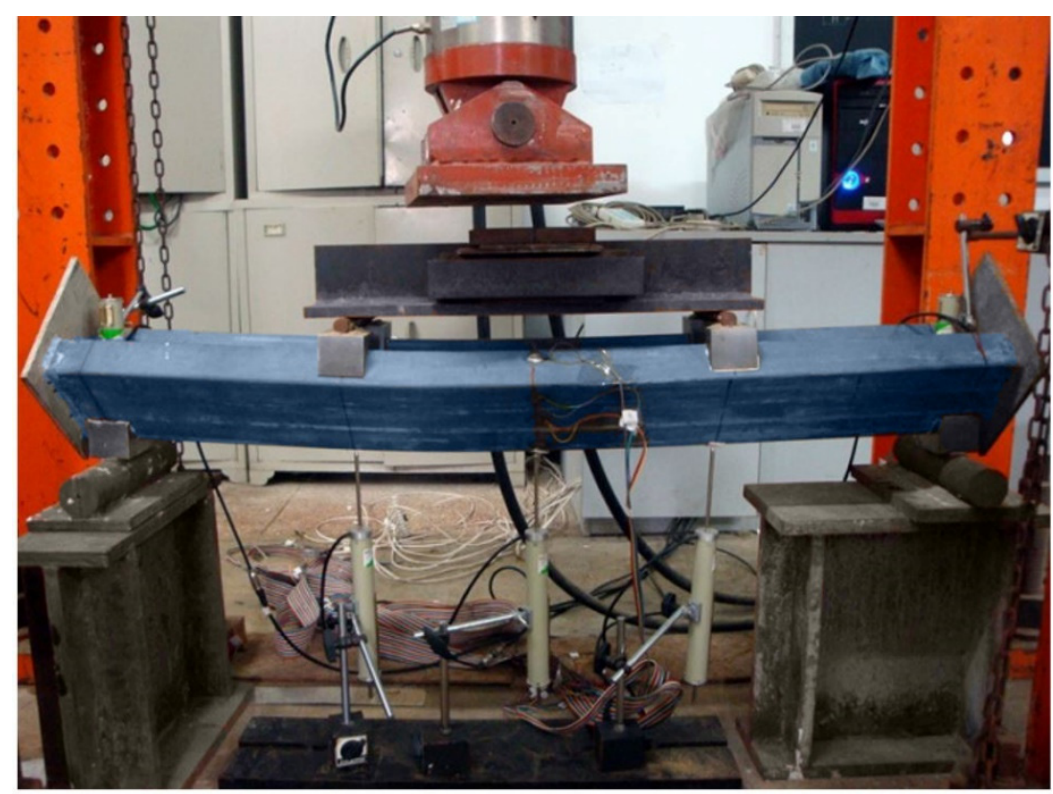

Figure 11. An overall view of the four-point bending test.

Considering that the composite L-section was symmetric about the major principal axis, four longitudinal strain gauges were attached to the faces at the mid-span of the specimen as shown in Figure 12. These were named G1, G2, G3, and G4. G1 and G4 were used to measure the strains at the extreme fibers of the L-sections. Since the strain gauges were not able to be mounted at the round external corners of the tubes, the positions of G1 and G4 were 2t (two times the wall thickness) from the corresponding external corner. For specimens with the load at the toes, G2 was 6t (six times the wall thickness) from the corresponding external corner, and G3 was placed near the centroid axis, while the positions of G2 and G3 were exchanged for specimens with the load at the heel. All the strain gauges were away from the butt welds on the steel tubes.

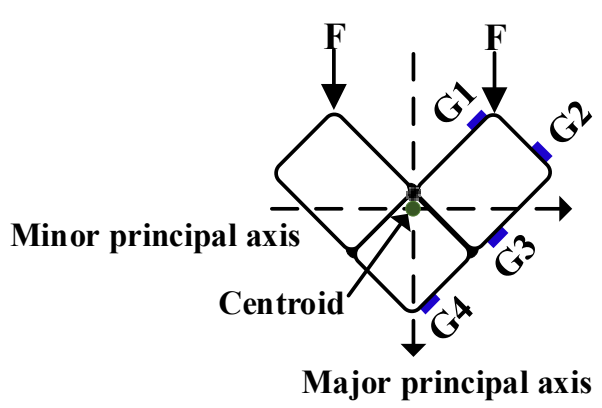

(a)

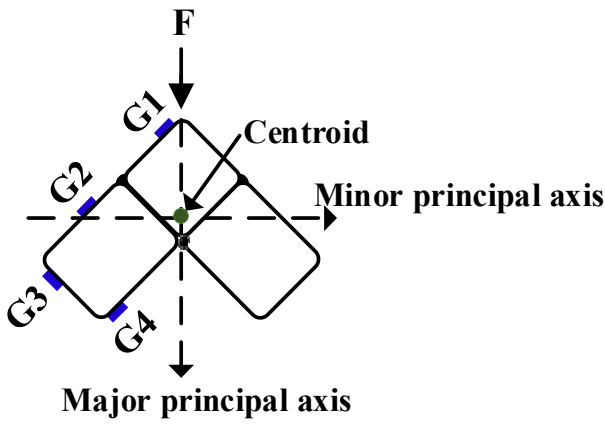

(b)

Figure 12. Position of longitudinal strain gauges: (a) Load at the toes; (b) Load at the heel.

\subsection{Failure Modes and Moment Versus Deflection Curves}

A general view of all the ML-CFST specimens after the test is shown in Figure 13. Lateral torsional buckling (instability) was not observed throughout the loading history. 
No brittle failure of the weld occurred, which ensured the good integrity of the multicell composite section. Due to the existence of concrete infill, which prevented the steel tubes from deforming inward, outward local buckling near to the loading points in the compression region of the specimens was observed under large deformation.

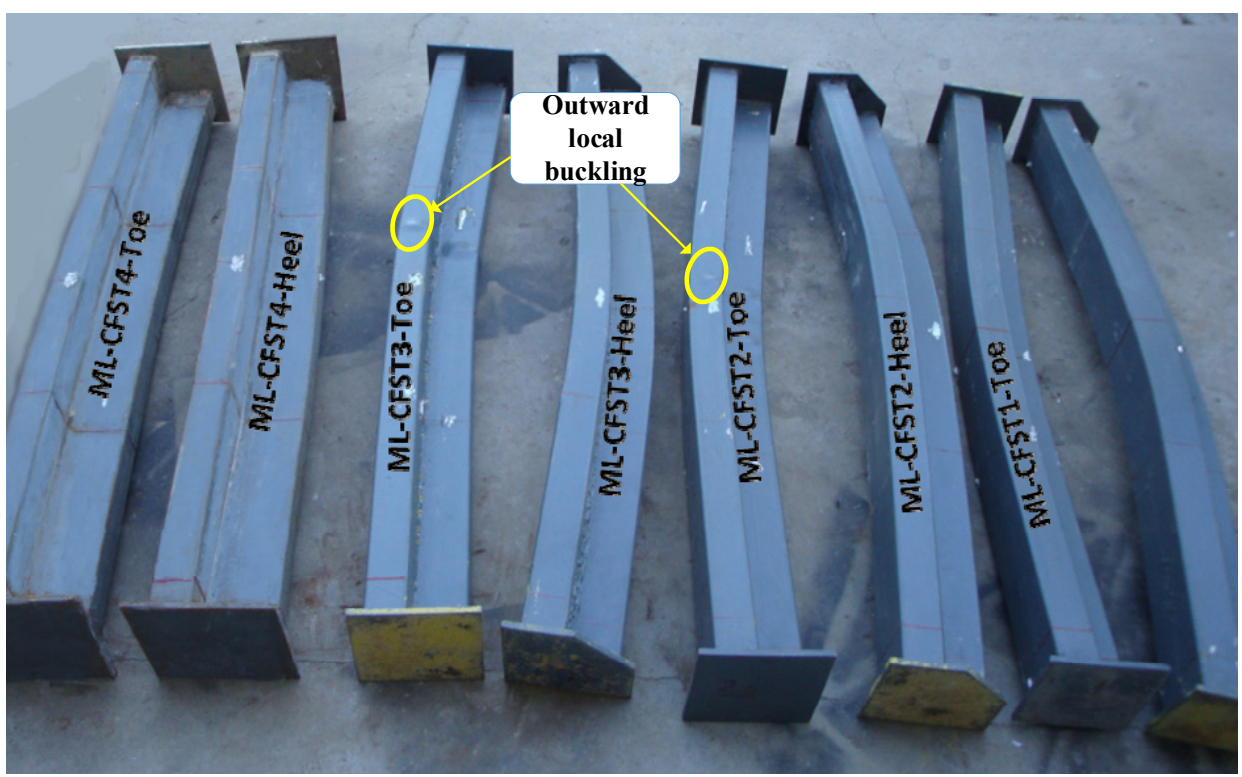

Figure 13. A general view of the ML-CFST specimens after the test.

The measured bending moment $(\mathrm{M})$ versus deflection $(\mathrm{U})$ curves for all specimens are shown in Figure 14. It was observed that all ML-CFST beams exhibited a moderate increase in bending moment resistance under large deformation, which demonstrated that they had very favorable ductile behavior. This was mainly attributed to the redistribution of stress in the composite section resulting from the failure of the infill concrete and the yielding or strain hardening of the steel. For each group, the obtained M-U curve for the specimen with the load at the toes was close to that for the counterpart with the load at the heel.

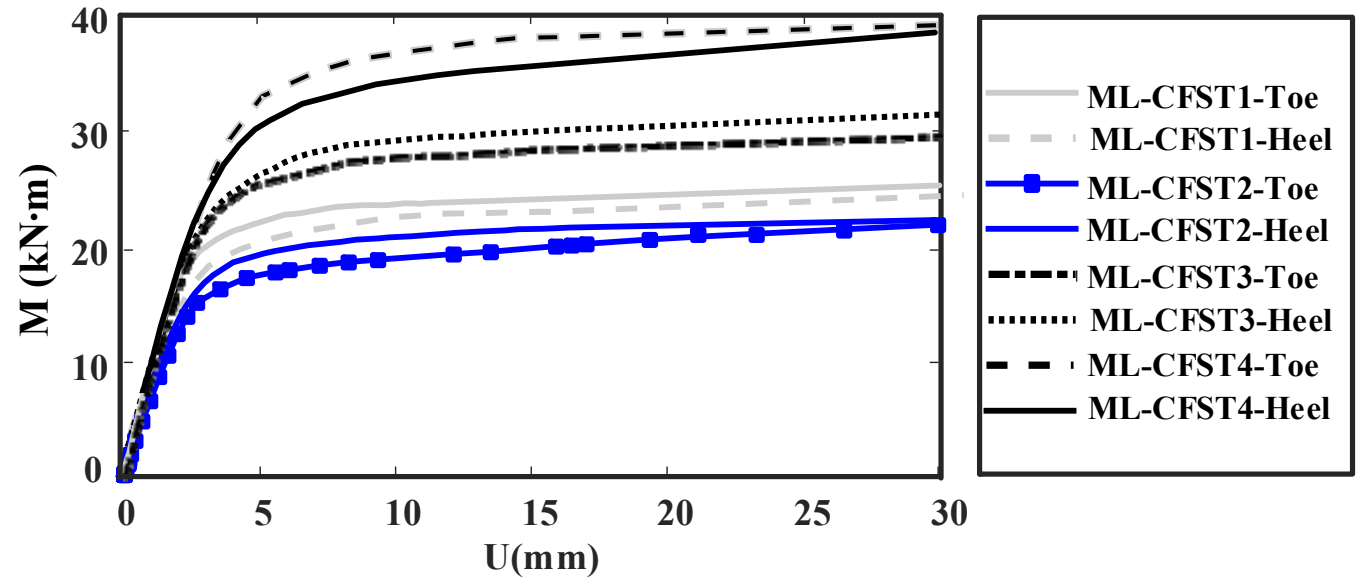

Figure 14. Bending moment (M) versus deflection (U) curves.

Many studies [16-22,30-32] have shown that the bending moment of a CFST beam does not descend until very large values of deflection are reached because of the redistribution of stress in the composite section. Since the mid-span deflection when the load first fell was far beyond the maximum allowable value specified in the design code [13], it was not appropriate to take the peak point of the $\mathrm{M}-\mathrm{U}$ curve as the ultimate bending moment, and the following descending branch of the $\mathrm{M}-\mathrm{U}$ curve was not what we needed. 
It should be noted that there are some differences in the definition of the ultimate bending moment of CFST beams among the reported studies due to different specimen configurations and experimental methods, among other factors. The ultimate bending moment was defined as the bending moment corresponding to the mid-span deflection of L/50 (L is the span of the beam) in [31,32]. The ratio of $\mathrm{L} / 50$ is the maximum allowable value of deflection for CFST beams specified in the Chinese design standard GB 50936-2014 [13]. Some other researchers $[16,19,20,33,34]$ have used the bending moment corresponding to an extreme fiber strain of 0.01 at the mid-span section as the ultimate bending moment in pure bending tests. Han [19] and Han et al. [20] reported that the moment tended to stabilize for conventional CFST beams after the maximum extreme fiber strain reached 0.01 .

This study did not attempt to justify which method was more appropriate for defining the ultimate bending moments of ML-CFST beams. The former definition method was adopted in the present paper, and the ultimate bending moment was denoted by $\mathrm{M}_{\mathrm{u}-\exp }$. For all the tested ML-CFST beams, L/50 =1200/50 $=24 \mathrm{~mm}$. Considering all the remarks mentioned above, the test was terminated when the deflection at the mid-span was greater than $30 \mathrm{~mm}$. The values of $\mathrm{M}_{\mathrm{u} \text {-exp }}$ for all specimens are shown in Table 1 . The difference in $\mathrm{M}_{\mathrm{u} \text {-exp }}$ of the two identical specimens for each group was found to be no more than $6 \%$.

As expected, the ML-CFST4 specimens with the largest $(b+a) / a$ ratio of 2.7 exhibited the highest bending stiffness and bending moment resistance, followed by ML-CFST3 specimens with the $(b+a) / a$ ratio of 2.3. Compared with the counterparts in the third and fourth groups, a considerable reduction in the ultimate bending moments of the ML-CFST1 specimens with $a b / a$ ratio of 2.0 was observed. The influence of the $(b+a) / a$ ratio on the flexural capacity of the studied ML-CFST specimens is depicted in Figure 15. With the $(b+a) / a$ ratio varying from 2.0 to $2.3, \mathrm{M}_{\mathrm{u} \text {-exp }}$ increased by $28 \%$ for the specimen with the load at the heel (ML-CFST3-Heel) and 17\% for the specimen with the load at the toes (ML-CFST3-Toe). As the $(\mathrm{b}+\mathrm{a}) / \mathrm{a}$ ratio went from 2.0 to $2.7, \mathrm{M}_{\mathrm{u} \text {-exp }}$ rose by $58 \%$ for $\mathrm{ML}$ CFST4-Heel and 60\% for ML-CFST4-Toe. This demonstrated that the depth-to-width ratio of the legs had a noticeable influence on the bending resistances of the ML-CFST beams.

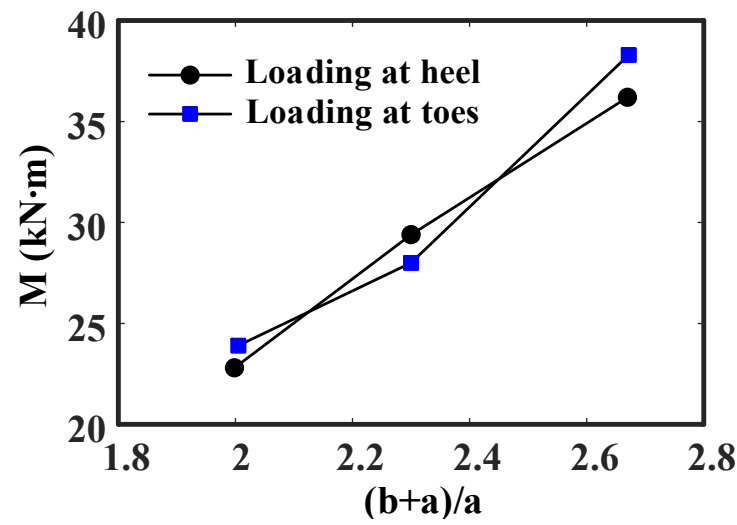

Figure 15. Measured ultimate bending moment $\left(\mathrm{M}_{\mathrm{u}-\exp }\right)$ versus $\mathrm{b} / \mathrm{a}$ ratio.

With a decrease in the wall thickness of the steel tubes, the ultimate bending moment of the ML-CFST2 specimens decreased by around $25 \%$ and was accompanied by a noticeable decrease in the initial flexural stiffness compared with the counterparts (ML-CFST3 specimens). The results showed that the wall thickness of the steel tubes had a significant influence on the ultimate bending moment and the initial flexural stiffness of the specimens. One explanation for this is that the flexural behavior of the ML-CFST beam was mainly dominated by materials close to the outside of the composite section.

\subsection{Measured Strain}

The measured longitudinal strain $(\varepsilon)$ versus bending moment $(\mathrm{M})$ curves for some typical specimens are shown in Figure 16, where the negative and positive strain correspond to compression and tension, respectively. It was observed that the measured $\varepsilon-\mathrm{M}$ curves 
almost maintained a linear result in the initial elastic stage. The yield time of the steel at different section positions varied. After the yielding of steel, the longitudinal strains grew at a much faster rate than the bending moment as the deflection increased. Compared with G2 and G3, G1 and G4 had shorter elastic stages and reached the yield strain earlier, as they were further away from the initial neutral axis (the minor principal axis was taken as the initial neutral axis under pure bending). Note that the nonlinear relationships between the longitudinal strains and the bending moments at different positions of the composite section were affected by the local buckling of steel and the cracking (crushing) of the infill concrete. The longitudinal strain at the G4 point developed faster than that at the G1 point for ML-CFST4-Heel, while the opposite trend was observed for ML-CFST4-Toe. This is because the asymmetric minor principal axis was closer to the heel of the two ML-CFST4 sections.

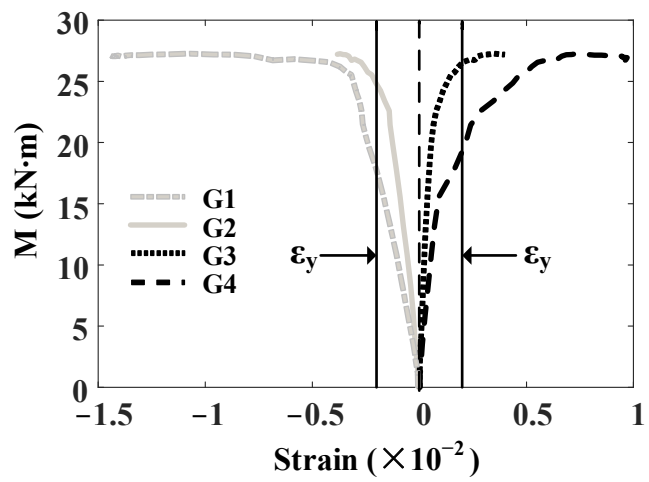

(a) ML-CFST3-Toe

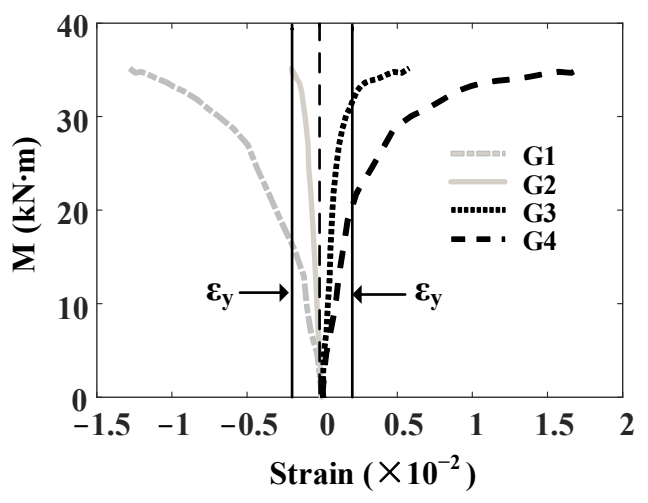

(c) ML-CFST4-Toe

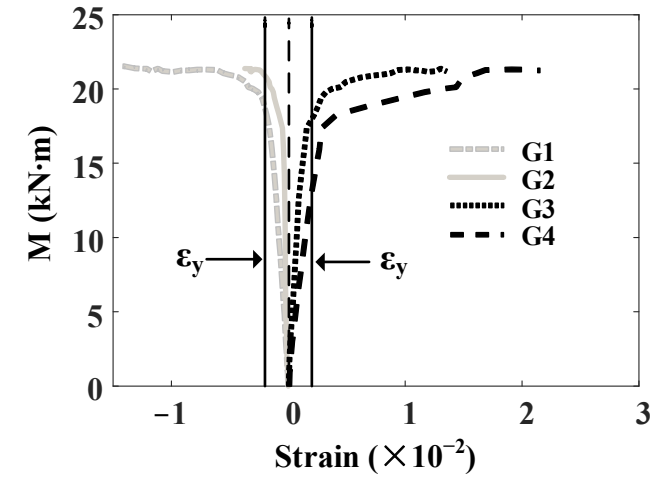

(b) ML-CFST2-Heel

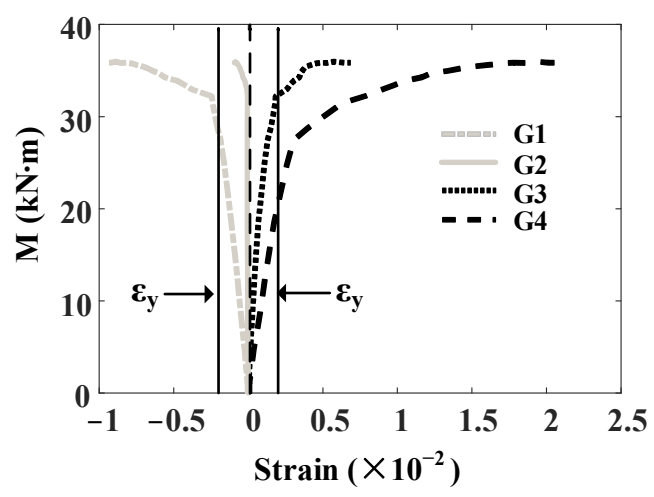

(d) ML-CFST4-Heel

Figure 16. Longitudinal strain $(\varepsilon)$ versus bending moment $(\mathrm{M})$ curves: (a) ML-CFST3-Toe; (b) MLCFST2-Heel; (c) ML-CFST4-Toe; (d) ML-CFST4-Heel.

Figure 17 shows the steel tube's strain distributions at the mid-span under five different loading levels (0.2 $\mathrm{M}_{\mathrm{u} \text {-exp }}, 0.4 \mathrm{M}_{\mathrm{u} \text {-exp }}, 0.6 \mathrm{M}_{\mathrm{u} \text {-exp }}, 0.8 \mathrm{M}_{\mathrm{u} \text {-exp }}$, and $\left.\mathrm{M}_{\mathrm{u} \text {-exp }}\right)$ for four typical specimens, where the horizontal axis denotes the longitudinal strain and the vertical axis denotes the distance from the centroid of an ML-CFST section. It was observed that the initial neutral axes of the composite sections at the mid-span almost coincided with the minor principal axes. The longitudinal strains were found to vary approximately linearly along the height of the composite section when the bending moments were less than $0.8 \mathrm{M}_{\mathrm{u} \text {-exp. }}$. This was aligned with the plane section assumption and demonstrated that the multi-cell composite L-shaped section functioned well as a unified entity. At the loading level of $\mathrm{M}_{\mathrm{u} \text {-exp }}$, large discrepancies were observed. These were attributed to the stress redistribution of the ML-CFST section caused by the tensile cracking or compressive crushing of the concrete. The movements of the initial neutral axes for these specimens 
were relatively small, and they varied because of the different sectional configurations (e.g., shifting upward for ML-CFST3-Toe and downward for ML-CFST4-Heel).

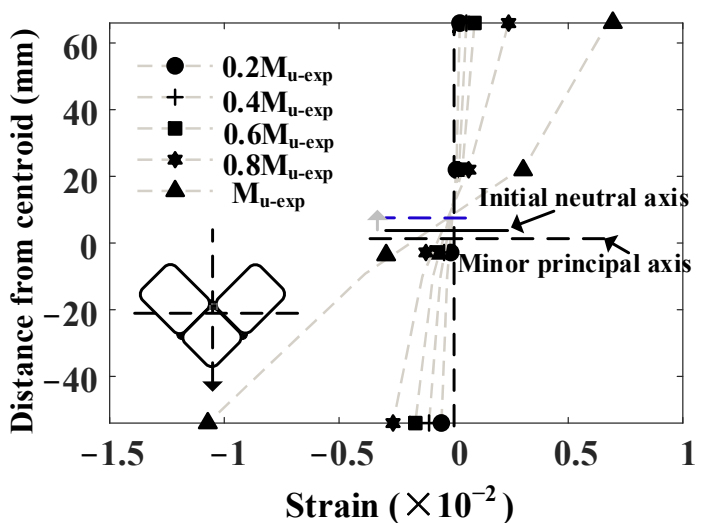

(a) ML-CFST3-Toe

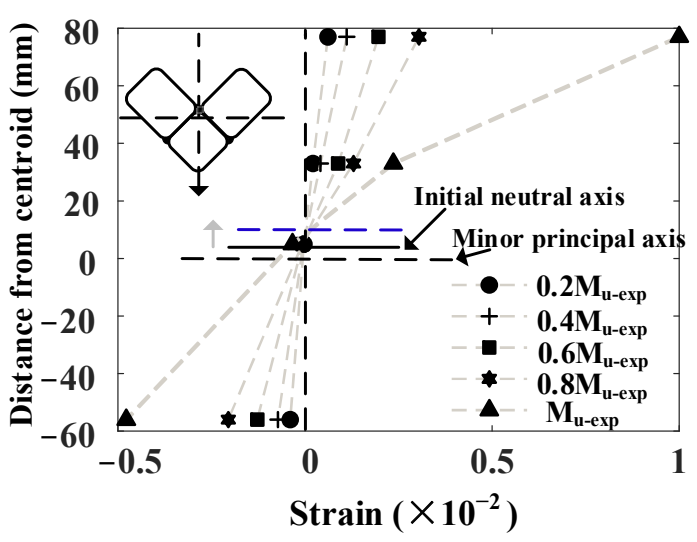

(c) ML-CFST4-Toe

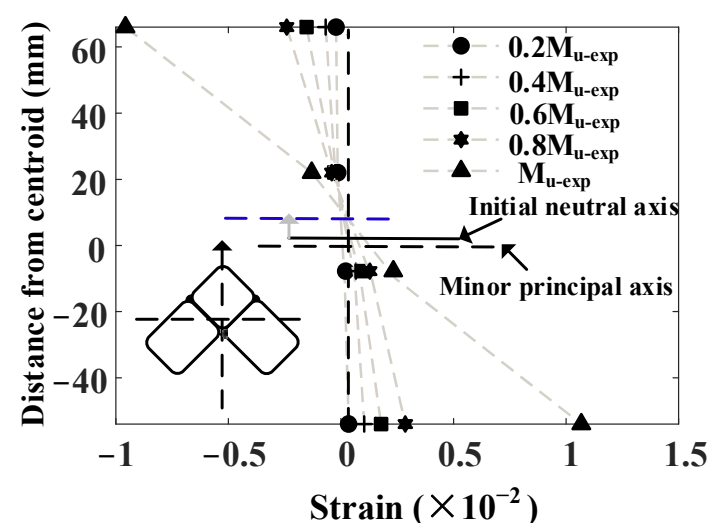

(b) ML-CFST2-Heel

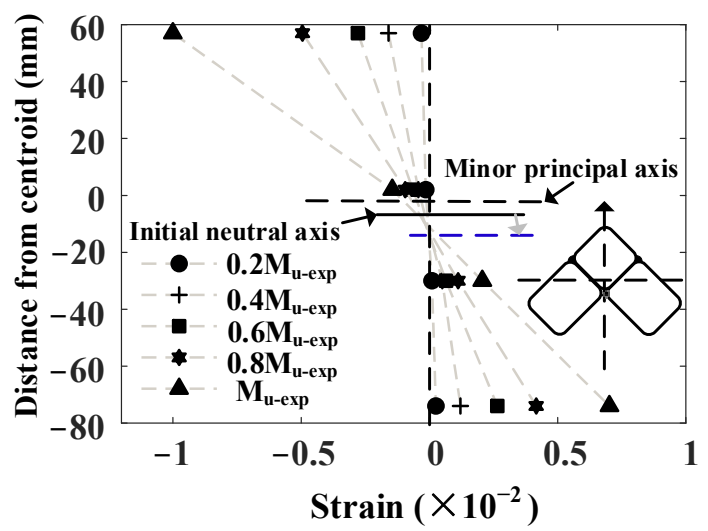

(d) ML-CFST4-Heel

Figure 17. Strain distributions of typical specimens: (a) ML-CFST3-Toe; (b) ML-CFST2-Heel; (c) MLCFST4-Toe; (d) ML-CFST4-Heel.

7. Comparison of Predicted Results from the Proposed Formula against the Experimental and Numerical Results

Based on the numerical modeling method mentioned in Section 5.1, a total of $20 \mathrm{ML}-$ CFST models with varied cross-sectional dimensions and material properties were developed to generate further data on the bending moment resistance of ML-CFST beams. The bending moment resistance of the ML-CFST beams obtained from the test, the proposed unified theory-based formula, and the FE models are denoted by $\mathrm{M}_{\mathrm{u}-\exp }, \mathrm{M}_{\mathrm{u} \text {-uni }}$, and $\mathrm{M}_{\mathrm{u}-\mathrm{FE}}$, respectively. $\mathrm{M}_{\mathrm{u} \text {-uni }}$ is equal to $\gamma_{\mathrm{m}} \mathrm{W}_{\mathrm{sc}} \mathrm{f}_{\mathrm{sc}}$, in which $\mathrm{f}_{\mathrm{sc}}$ is determined by the proposed Equation (18) and $\gamma_{\mathrm{m}}$ is determined by the proposed Equation (20). The detailed results for $\mathrm{M}_{\mathrm{u} \text {-uni }} / \mathrm{M}_{\mathrm{u} \text {-exp }}$ and $\mathrm{M}_{\mathrm{u} \text {-uni }} / \mathrm{M}_{\mathrm{u} \text {-FE }}$ are shown in Table 2. The experimental results, together with the numerically generated data, were compared against the results predicted by the proposed formula, as shown in Figure 18. 
Table 2. Detailed results of $\mathrm{M}_{\mathrm{u}-\mathrm{uni}}$ and $\mathrm{M}_{\mathrm{u}-\mathrm{FE}}$ for the studied ML-CFST beams.

\begin{tabular}{|c|c|c|c|c|c|c|c|c|}
\hline ML-CFST Beams & a (mm) & b (mm) & $t(\mathrm{~mm})$ & $(b+a) / a$ & $\mathrm{f}_{\mathbf{y}}$ (MPa) & $\mathbf{f}_{\mathrm{c}}^{\prime}$ (MPa) & $\mathbf{M}_{\mathbf{u}-\mathbf{u n i}} / \mathbf{M}_{\mathbf{u}-\exp }$ & $\mathbf{M}_{\mathrm{u} \text {-uni }} / \mathbf{M}_{\mathbf{u}-\mathrm{FE}}$ \\
\hline \multirow{8}{*}{8 test specimens } & 60.2 & 60.1 & 2.5 & 2.0 & 298.1 & 42.2 & 1.01 & \\
\hline & 59.7 & 60.0 & 2.5 & 2.0 & 298.1 & 42.2 & 0.92 & \\
\hline & 59.9 & 79.5 & 2.0 & 2.3 & 306.0 & 42.2 & 0.84 & \\
\hline & 60.1 & 80.0 & 2.0 & 2.3 & 306.0 & 42.2 & 0.96 & \\
\hline & 60.0 & 80.1 & 2.5 & 2.3 & 298.1 & 42.2 & 1.07 & \\
\hline & 60.4 & 79.9 & 2.5 & 2.3 & 298.1 & 42.2 & 0.87 & \\
\hline & 60.2 & 100.5 & 2.5 & 2.7 & 298.1 & 42.2 & 0.95 & \\
\hline & 60.0 & 100.3 & 2.5 & 2.7 & 298.1 & 42.2 & 0.91 & \\
\hline \multirow{20}{*}{20 FE models } & 100 & 120 & 3.0 & 2.2 & 250 & 45 & & 0.96 \\
\hline & 90 & 140 & 2.5 & 2.6 & 450 & 50 & & 0.99 \\
\hline & 150 & 150 & 4.0 & 2.0 & 370 & 55 & & 0.90 \\
\hline & 150 & 200 & 5.0 & 2.3 & 600 & 60 & & 1.04 \\
\hline & 120 & 120 & 4.5 & 2.0 & 450 & 80 & & 0.96 \\
\hline & 80 & 100 & 2.0 & 2.3 & 600 & 50 & & 1.06 \\
\hline & 100 & 150 & 3.0 & 2.5 & 370 & 35 & & 0.98 \\
\hline & 80 & 80 & 2.5 & 2.0 & 300 & 55 & & 1.05 \\
\hline & 60 & 100 & 2.0 & 2.7 & 450 & 65 & & 0.89 \\
\hline & 120 & 200 & 4.0 & 2.7 & 370 & 40 & & 1.09 \\
\hline & 100 & 120 & 2.5 & 2.2 & 450 & 30 & & 0.91 \\
\hline & 90 & 140 & 3.0 & 2.6 & 600 & 45 & & 0.97 \\
\hline & 150 & 150 & 5.0 & 2.0 & 450 & 60 & & 0.89 \\
\hline & 150 & 200 & 4.0 & 2.3 & 500 & 45 & & 0.95 \\
\hline & 120 & 120 & 3.0 & 2.0 & 370 & 55 & & 1.02 \\
\hline & 80 & 100 & 2.5 & 2.3 & 450 & 30 & & 0.92 \\
\hline & 100 & 150 & 4.0 & 2.5 & 250 & 45 & & 1.13 \\
\hline & 80 & 80 & 2.0 & 2.0 & 450 & 65 & & 0.93 \\
\hline & 60 & 100 & 2.5 & 2.7 & 600 & 55 & & 0.99 \\
\hline & 120 & 200 & 3.0 & 2.7 & 450 & 45 & & 0.95 \\
\hline$\mu$ & & & & & & & 0.94 & 0.98 \\
\hline $\mathrm{COV}$ & & & & & & & 0.08 & 0.07 \\
\hline$\varepsilon+$ & & & & & & & $+7 \%$ & $+13 \%$ \\
\hline$\varepsilon-$ & & & & & & & $-16 \%$ & $-12 \%$ \\
\hline
\end{tabular}

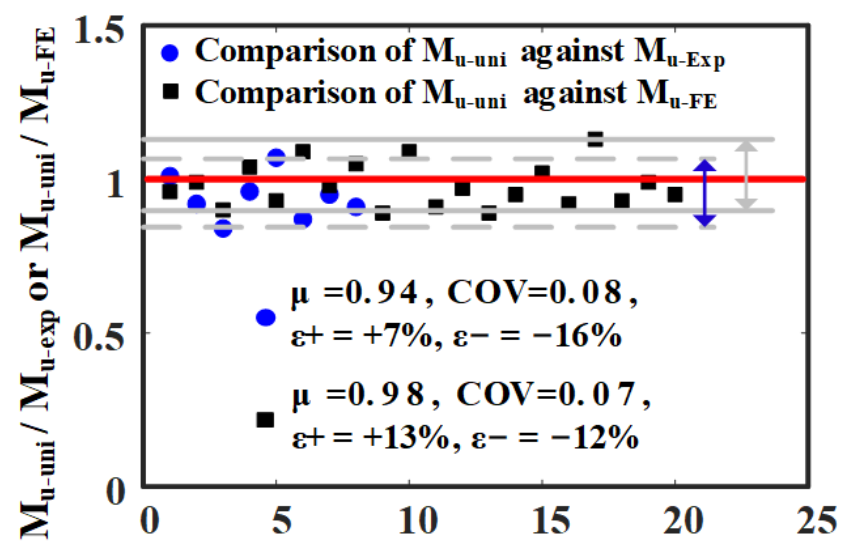

The number of the studied ML-CFST beams

Figure 18. Comparison of the results predicted by the proposed approach against the experimental and numerical results.

The mean values for $\mathrm{M}_{\mathrm{u} \text {-uni }} / \mathrm{M}_{\mathrm{u} \text {-exp }}$ and $\mathrm{M}_{\mathrm{u} \text {-uni }} / \mathrm{M}_{\mathrm{u} \text {-FE }}$ were 0.94 and 0.98 , respectively, while the COVs of $\mathrm{M}_{\mathrm{u}-\mathrm{uni}} / \mathrm{M}_{\mathrm{u}-\exp }$ and $\mathrm{M}_{\mathrm{u}-\mathrm{uni}} / \mathrm{M}_{\mathrm{u}-\mathrm{FE}}$ were 0.08 and 0.07 , respectively. This shows that the predicted results by the proposed approach agreed well with both the experimental results and the numerical results. In comparison with the test results, the unified theory-based formula underestimated the bending moment resistance of most specimens by $4-16 \%$, whereas it produced unconservative errors within $7 \%$ for two specimens. Considering that safety factors of greater than 1.0 were specified in the design codes and specifications, the unconservative errors were deemed to be low and acceptable. With the 
ratios of $\mathrm{M}_{\mathrm{u}-\mathrm{uni}} / \mathrm{M}_{\mathrm{u}-\mathrm{FE}}$ being less than one for most cases, the proposed formula generally produced conservative predictions for the FE models. These results demonstrate that the unified theory-based approach gave safe and reasonably accurate predictions for the ML-CFST beams. The results also indicated that the proposed formula for calculating the compressive strength of the composite section, in which the effect of the cross-section shape and boundary conditions on confinement was considered by introducing an equivalent shape factor, was sound for the ML-CFST sections.

\section{Conclusions}

In this paper, numerical and experimental investigations to evaluate the bending moment resistance of ML-CFST beams are presented. An equivalent shape factor $\left(\mathrm{K}_{\text {equi }}\right)$ to modify the confinement effect for ML-CFST cross-sections was proposed to overcome the inadequacy of the existing confinement effect factor. Adequate formulas that depend on $\mathrm{K}_{\text {equi }}$ were then developed to determine the compressive strength $\left(\mathrm{f}_{\mathrm{sc}}\right)$ of an ML-CFST cross-section and the flexural strength index $\left(\gamma_{\mathrm{m}}\right)$. The bending moment resistance of an ML-CFST beam in accordance with the unified theory was determined by $\mathrm{f}_{\mathrm{sc}} \cdot \gamma_{\mathrm{m}} \cdot \mathrm{W}_{\mathrm{sc}}$. Based on the information presented in this paper, the following conclusions were drawn:

(1) The proposed equivalent shape factor, in which the influence of the cross-sectional geometry and boundary condition of the cells on confinement was taken into consideration through dividing the infill concrete into highly confined areas and less confined areas, was reasonable for the ML-CFST cross-sections. This improved the applicability of the unified theory to special-shaped CFST cross-sections.

(2) All the test ML-CFST beams had a moderate increase in the bending moment resistance under large deformation values and exhibited very favorable ductile behavior. This was mainly attributed to stress redistribution in the composite section caused by the failure of the infill concrete and the yielding or strain hardening of steel. The depth-to-width ratio of the section legs had a noticeable influence on the bending moment resistance of the ML-CFST specimens.

(3) The results determined by the proposed formula agreed well with both the experimental results and the numerical results. For most ML-CFST beams, the proposed formula gave reasonably conservative errors, while it produced acceptable unconservative predictions for a few cases. The results demonstrated that the adopted unified theory was applicable for evaluating the bending moment resistance of ML-CFST beams.

Furthermore, reliability analysis should be conducted to investigate whether the reliability requirements of the proposed approach are satisfied, and the applicability of the proposed approach for other special-shaped CFST beams should be assessed in the future.

Author Contributions: Funding acquisition, Y.T.; investigation, Y.S. and W.H.; methodology, Y.S.; supervision, Y.T.; validation, Y.S.; writing—original draft, Y.S.; writing—review and editing, Y.T. All authors have read and agreed to the published version of the manuscript.

Funding: This research was sponsored by the National Natural Science Foundation of China, grant number 51278019.

Institutional Review Board Statement: Not applicable.

Informed Consent Statement: Not applicable.

Conflicts of Interest: The authors declare no conflict of interest. 


\section{Appendix A}

Table A1. Details on the 50 ML-CFST stub column and 50 ML-CFST beam models.

\begin{tabular}{|c|c|c|c|c|c|c|c|c|c|c|}
\hline \multirow[b]{2}{*}{ a (mm) } & \multirow[b]{2}{*}{ b (mm) } & \multirow[b]{2}{*}{$\mathrm{t}(\mathrm{mm})$} & \multirow{2}{*}{$\begin{array}{l}\text { (b + } \\
\text { a)/a }\end{array}$} & \multirow{2}{*}{$\begin{array}{c}\mathbf{f}_{\mathbf{y}} \\
(\mathbf{M P a})\end{array}$} & \multirow{2}{*}{$\begin{array}{c}\mathbf{f}_{\mathrm{c}} \\
(\mathbf{M P a})\end{array}$} & \multirow{2}{*}{$\begin{array}{c}\text { Column } \\
\mathbf{f}_{\text {sc-uni }} / \\
\mathbf{f}_{\text {sc-FE }}\end{array}$} & \multicolumn{4}{|c|}{ Beam } \\
\hline & & & & & & & $L /(b+a)$ & Loading Point & $\xi \mathbf{K}_{\text {equi-av }}$ & $\gamma_{\mathrm{m}}$ \\
\hline 60 & 120 & 2.0 & 3.0 & 250 & 30 & 0.89 & 7.0 & Toe & 1.0 & 0.90 \\
\hline 80 & 140 & 2.5 & 2.8 & 450 & 45 & 0.99 & 9.0 & Heel & 1.1 & 1.72 \\
\hline 100 & 150 & 3.0 & 2.5 & 370 & 55 & 0.89 & 10.0 & Heel & 0.8 & 0.53 \\
\hline 120 & 200 & 4.0 & 2.7 & 600 & 45 & 1.03 & 12.0 & Heel & 1.6 & 2.52 \\
\hline 140 & 140 & 4.5 & 2.0 & 450 & 80 & 0.99 & 7.0 & Toe & 0.8 & 0.77 \\
\hline 150 & 180 & 6.0 & 2.2 & 600 & 30 & 0.81 & 9.0 & Toe & 3.4 & 3.55 \\
\hline 110 & 132 & 6.0 & 2.2 & 370 & 45 & 0.96 & 10.0 & Heel & 2.0 & 2.42 \\
\hline 80 & 80 & 2.5 & 2.0 & 250 & 35 & 1.02 & 12.0 & Toe & 1.0 & 0.90 \\
\hline 100 & 100 & 3.0 & 2.0 & 450 & 65 & 1.11 & 7.0 & Toe & 0.9 & 1.24 \\
\hline 120 & 200 & 6.0 & 2.7 & 370 & 40 & 0.88 & 9.0 & Toe & 1.8 & 2.37 \\
\hline 140 & 140 & 4.5 & 2.0 & 600 & 30 & 0.97 & 10.0 & Heel & 2.6 & 3.42 \\
\hline 150 & 180 & 6.0 & 2.2 & 600 & 45 & 0.86 & 12.0 & Toe & 2.3 & 2.74 \\
\hline 60 & 60 & 2.0 & 2.0 & 370 & 55 & 0.99 & 7.0 & Toe & 1.0 & 0.99 \\
\hline 80 & 136 & 2.5 & 2.7 & 500 & 45 & 1.05 & 9.0 & Toe & 1.3 & 1.73 \\
\hline 100 & 100 & 3.0 & 2.0 & 600 & 55 & 1.00 & 10.0 & Heel & 1.4 & 2.01 \\
\hline 120 & 200 & 4.0 & 2.7 & 450 & 30 & 0.91 & 12.0 & Toe & 1.8 & 2.68 \\
\hline 140 & 140 & 4.5 & 2.0 & 500 & 45 & 1.06 & 7.0 & Heel & 1.6 & 2.08 \\
\hline 150 & 180 & 6.0 & 2.2 & 450 & 55 & 0.95 & 9.0 & Toe & 1.4 & 1.42 \\
\hline 60 & 120 & 2.5 & 3.0 & 250 & 65 & 0.87 & 10.0 & Heel & 0.6 & 0.30 \\
\hline 80 & 120 & 2.5 & 2.5 & 450 & 45 & 1.01 & 12.0 & Heel & 1.2 & 1.55 \\
\hline 100 & 100 & 3.0 & 2.0 & 450 & 30 & 0.85 & 7.0 & Toe & 2.0 & 2.72 \\
\hline 120 & 180 & 4.5 & 2.5 & 450 & 45 & 0.84 & 9.0 & Toe & 1.5 & 1.79 \\
\hline 140 & 140 & 4.5 & 2.0 & 500 & 55 & 0.99 & 10.0 & Toe & 1.3 & 1.51 \\
\hline 150 & 180 & 6.0 & 2.2 & 600 & 65 & 0.95 & 12.0 & Heel & 1.6 & 2.33 \\
\hline 60 & 120 & 2.0 & 3.0 & 500 & 80 & 1.03 & 7.0 & Toe & 0.7 & 0.62 \\
\hline 80 & 120 & 2.5 & 2.5 & 500 & 30 & 0.92 & 9.0 & Toe & 2.0 & 2.62 \\
\hline 100 & 100 & 3.0 & 2.0 & 370 & 45 & 0.99 & 10.0 & Toe & 1.1 & 1.41 \\
\hline 120 & 144 & 4.0 & 2.2 & 450 & 55 & 1.09 & 12.0 & Toe & 1.1 & 1.25 \\
\hline 140 & 140 & 4.5 & 2.0 & 500 & 65 & 0.84 & 7.0 & Heel & 1.1 & 1.33 \\
\hline 150 & 180 & 6.0 & 2.2 & 600 & 45 & 1.12 & 9.0 & Toe & 2.5 & 3.20 \\
\hline 60 & 102 & 2.0 & 2.7 & 250 & 30 & 1.02 & 10.0 & Heel & 1.0 & 1.11 \\
\hline 80 & 80 & 2.5 & 2.0 & 300 & 45 & 0.88 & 12.0 & Toe & 0.9 & 0.88 \\
\hline 100 & 150 & 3.0 & 2.5 & 370 & 55 & 1.00 & 7.0 & Heel & 0.8 & 0.57 \\
\hline 120 & 200 & 4.0 & 2.7 & 450 & 65 & 0.90 & 9.0 & Heel & 0.9 & 0.84 \\
\hline 140 & 140 & 4.5 & 2.0 & 500 & 80 & 1.06 & 10.0 & Toe & 0.9 & 0.89 \\
\hline 150 & 150 & 6.0 & 2.0 & 600 & 30 & 0.88 & 12.0 & Toe & 3.7 & 4.00 \\
\hline 60 & 72 & 2.0 & 2.2 & 500 & 45 & 0.81 & 7.0 & Toe & 1.5 & 2.01 \\
\hline 80 & 140 & 2.5 & 2.8 & 300 & 35 & 1.10 & 9.0 & Heel & 1.0 & 1.23 \\
\hline 100 & 150 & 4.5 & 2.5 & 370 & 65 & 0.81 & 10.0 & Toe & 1.0 & 1.15 \\
\hline 120 & 200 & 4.0 & 2.7 & 450 & 80 & 0.94 & 12.0 & Heel & 0.7 & 0.72 \\
\hline 140 & 140 & 4.5 & 2.0 & 600 & 30 & 0.92 & 7.0 & Toe & 2.8 & 3.16 \\
\hline 150 & 180 & 6.0 & 2.2 & 600 & 45 & 0.98 & 9.0 & Heel & 2.3 & 2.74 \\
\hline 60 & 120 & 2.0 & 3.0 & 370 & 55 & 1.00 & 10.0 & Heel & 0.8 & 0.51 \\
\hline 80 & 140 & 3.0 & 2.8 & 450 & 65 & 0.93 & 12.0 & Toe & 1.0 & 1.32 \\
\hline 100 & 100 & 3.0 & 2.0 & 370 & 80 & 0.92 & 7.0 & Toe & 0.6 & 0.43 \\
\hline 120 & 200 & 4.0 & 2.7 & 450 & 30 & 1.00 & 9.0 & Toe & 1.8 & 2.45 \\
\hline 140 & 140 & 4.5 & 2.0 & 500 & 45 & 1.05 & 10.0 & Heel & 1.6 & 2.42 \\
\hline 150 & 180 & 6.0 & 2.2 & 600 & 45 & 0.94 & 12.0 & Toe & 2.3 & 2.94 \\
\hline 100 & 150 & 4.0 & 2.5 & 450 & 65 & 0.85 & 9.0 & Heel & 1.1 & 1.27 \\
\hline 80 & 160 & 4.0 & 3.0 & 300 & 30 & 1.05 & 10.0 & Heel & 1.8 & 2.41 \\
\hline$\mu$ & & & & & & 0.96 & & & & \\
\hline $\mathrm{COV}$ & & & & & & 0.09 & & & & \\
\hline $\mathcal{E}+$ & & & & & & $12 \%$ & & & & \\
\hline$\varepsilon-$ & & & & & & $-19 \%$ & & & & \\
\hline
\end{tabular}

\section{References}

1. Le, K.B.; Van Cao, V. Numerical Study of Circular Concrete Filled Steel Tubes Subjected to Pure Torsion. Buildings 2021, $11,397$. [CrossRef]

2. Tort, C.; Hajjar, J.F. Mixed Finite-Element Modeling of Rectangular Concrete-Filled Steel Tube Members and Frames under Static and Dynamic Loads. J. Struct. Eng. 2010, 136, 654-664. [CrossRef] 
3. Gunawardena, Y.; Aslani, F. Finite element modelling of concrete-filled spiral-welded mild-steel and stainless-steel tubes in flexure. Structures 2021, 32, 792-816. [CrossRef]

4. Rush, D.; Bisby, L.; Jowsey, A.; Melandinos, A.; Lane, B. Structural performance of unprotected concrete-filled steel hollow sections in fire: A review and meta-analysis of available test data. Steel Compos. Struct. 2012, 12, 325-350. [CrossRef]

5. Liew, R.; Xiong, D. Ultra-High Strength Concrete Filled Composite Columns for Multi-Storey Building Construction. Adv. Struct. Eng. 2012, 15, 1487-1503. [CrossRef]

6. Lam, D.; Yang, J.; Dai, X. Context SensFinite element analysis of concrete filled lean duplex stainless steel columns. Structures 2019, 21, 150-155. [CrossRef]

7. Nguyen, H.Q.; Ly, H.-B.; Tran, V.Q.; Nguyen, T.-A.; Le, T.-T.; Pham, B.T. Optimization of Artificial Intelligence System by Evolutionary Algorithm for Prediction of Axial Capacity of Rectangular Concrete Filled Steel Tubes under Compression. Materials 2020, 13, 1205. [CrossRef] [PubMed]

8. Al-Nini, A.; Nikbakht, E.; Syamsir, A.; Shafiq, N.; Mohammed, B.S.; Al-Fakih, A.; Al-Nini, W.; Amran, Y.H.M. Flexural Behavior of Double-Skin Steel Tube Beams Filled with Fiber-Reinforced Cementitious Composite and Strengthened with CFRP Sheets. Materials 2020, 13, 3064. [CrossRef]

9. Brown, N.; Kowalsky, M.; Nau, J. Impact of D/t on seismic behavior of reinforced concrete filled steel tubes. J. Constr. Steel Res. 2015, 107, 111-123. [CrossRef]

10. Li, T.L.; Tu, Y.Q. Research on behavior of L-shaped multi-cell composite concrete-filled steel tubular short columns subjected to biaxial eccentric compression. Ind. Constr. 2018, 48, 156-161. (In Chinese) [CrossRef]

11. Eurocode 4: Design of Composite Steel and Concrete Structures-Part 1-1: General Rules and Rules for Buildings; European Committee for Standardization: Brussels, Belgium, 2004.

12. ANSI/AISC 360-16, Specification for Structural Steel Buildings; American Institute of Steel Construction: Chicago, IL, USA, 2016.

13. GB 50936-2014: Technical Code for Concrete Filled Steel Tubular Structures; China Architecture and Building Press: Beijing, China, 2014. (In Chinese)

14. Kuranovas, A.; Goode, D.; Kvedaras, A.K.; Zhong, S. Load-bearing capacity of concrete-filled steel columns. J. Civ. Eng. Manag. 2009, 15, 21-33. [CrossRef]

15. Han, L.-H.; Tao, Z.; Huang, H.; Zhao, X.-L. Concrete-filled double skin (SHS outer and CHS inner) steel tubular beam-columns. Thin-Walled Struct. 2004, 42, 1329-1355. [CrossRef]

16. Wang, R.; Han, L.-H.; Nie, J.-G.; Zhao, X.-L. Flexural performance of rectangular CFST members. Thin-Walled Struct. 2014, 79, 154-165. [CrossRef]

17. Javed, M.F.; Sulong, N.R.; Memon, S.A.; Rehman, S.K.U.; Khan, N.B. FE modelling of the flexural behaviour of square and rectangular steel tubes filled with normal and high strength concrete. Thin-Walled Struct. 2017, 119, 470-481. [CrossRef]

18. Li, G.; Liu, D.; Yang, Z.; Zhang, C. Flexural behavior of high strength concrete filled high strength square steel tube. J. Constr. Steel Res. 2016, 128, 732-744. [CrossRef]

19. Han, L.-H. Flexural behaviour of concrete-filled steel tubes. J. Constr. Steel Res. 2004, 60, 313-337. [CrossRef]

20. Han, L.-H.; Lu, H.; Yao, G.-H.; Liao, F.-Y. Further study on the flexural behaviour of concrete-filled steel tubes. J. Constr. Steel Res. 2006, 62, 554-565. [CrossRef]

21. Abed, F.; Abdelmageed, Y.; Alhoubi, Y. Effect of different cross-sections and concrete types on the flexural behavior of CFSTs. Compos. Struct. 2021, 276, 114570. [CrossRef]

22. Shen, Y.; Tu, Y. Flexural Strength Evaluation of Multi-Cell Composite T-Shaped Concrete-Filled Steel Tubular Beams. Materials 2021, 14, 2838. [CrossRef] [PubMed]

23. Lin, G.; Teng, J. Advanced stress-strain model for FRP-confined concrete in square columns. Compos. Part B Eng. 2020, 197, 108149. [CrossRef]

24. Megalooikonomou, K.G.; Papavasileiou, G.S. Analytical Stress-Strain Model for FRP-Confined Rectangular RC Columns. Front. Built Environ. 2019, 5, 39. [CrossRef]

25. Zuo, Z.-L.; Cai, J.; Yang, C.; Chen, Q.-J.; Sun, G. Axial load behavior of L-shaped CFT stub columns with binding bars. Eng. Struct. 2012, 37, 88-98. [CrossRef]

26. Abdel-Rahman, N.; Sivakumaran, K.S. Material Properties Models for Analysis of Cold-Formed Steel Members. J. Struct. Eng. 1997, 123, 1135-1143. [CrossRef]

27. Lee, J.; Fenves, G.L. Plastic-Damage Model for Cyclic Loading of Concrete Structures. J. Eng. Mech. 1998, 124, 892-900. [CrossRef]

28. Han, L.-H.; Yao, G.-H.; Tao, Z. Performance of concrete-filled thin-walled steel tubes under pure torsion. Thin-Walled Struct. 2007, 45, 24-36. [CrossRef]

29. Hognestad, E.; Hanson, N.W.; McHenry, D. Concrete stress distribution in ultimate stress design. ACI J. 1955, $27,455-479$.

30. Xiong, M.-X.; Xiong, D.-X.; Liew, R. Flexural performance of concrete filled tubes with high tensile steel and ultra-high strength concrete. J. Constr. Steel Res. 2017, 132, 191-202. [CrossRef]

31. Chen, Y.; Feng, R.; Wang, L. Flexural behaviour of concrete-filled stainless steel SHS and RHS tubes. Eng. Struct. 2017, 134, 159-171. [CrossRef]

32. Hassanein, M.; Kharoob, O.; Taman, M. Experimental investigation of cementitious material-filled square thin-walled steel beams. Thin-Walled Struct. 2017, 114, 134-143. [CrossRef] 
33. Gunawardena, Y.; Aslani, F. Static flexural behaviour of concrete-filled spiral-welded stainless-steel tubes. Thin-Walled Struct. 2020, 151, 106731. [CrossRef]

34. Yang, Y.-F.; Ma, G.-L. Experimental behaviour of recycled aggregate concrete filled stainless steel tube stub columns and beams. Thin-Walled Struct. 2013, 66, 62-75. [CrossRef] 